\title{
COMMENTS
}

\section{THE COLLATERAL-ESTOPPEL EFFEGT TO BE GIVEN STATE-COURT JUDGMENTS IN FEDERAL SEGTION 1983 DAMAGE SUITS}

Under 42 U.S.C. $\$ 1983,{ }^{1}$ litigants have a federal forum ${ }^{2}$ in which to seek redress for state deprivations of federal constitutional rights. $^{3}$ One such genre of claims involves suits by state criminal defendants seeking damages for constitutional torts suffered at the hands of state police or prosecutorial officials. ${ }^{4}$ The constitutional issue underlying the federal damage claim often has been decided against the litigant in the course of his state criminal trial or ancillary suppression hearing. Most federal courts have held the section 1983 plaintiff barred by the doctrine of collateral estoppel from relitigating the constitutional issue-or any underlying factthus effectively denying any relief under section $1983 .^{6}$

1 Every person who, under color of any statute, ordinance, regulation, custom, or usage, of any State or Territory, subjects, or causes to be subjected, any citizen of the United States or other person within the jurisdiction thereof to the deprivation of any rights, privileges, or immunities secured by the Constitution and laws, shall be liable to the party injured in an action at law, suit in equity, or other proper proceeding for redress. 42 U.S.C. $\$ 1983$ (1976).

This section was enacted as $\$ 1$ of the Civil Rights Act of 1871,17 Stat. 13 .

2 Original jurisdiction over $\$ 1983$ claims is conferred on the lower federal courts by 28 U.S.C. $\$ 1343(3)$ (1976). Federal jurisdiction, however, is not exclusive. See note 47 infra.

3 See Mitchum v. Foster, 407 U.S. 225, 238-42 (1972); Monroe v. Pape, 365 U.S. 167, 172-87 (1961), overruled in part on other grounds, Monell v. Department of Social Servs., 436 U.S. 658 (1978). See generally Developments in the Law-Section 1983 and Federalism, 90 Harv. L. REv. 1133 (1977) [hereinafter cited as Section 1983 Developments].

4 Monroe v. Pape, 365 U.S. 167 (1961), overruled in part on other grounds, Monell v. Department of Social Servs., 436 U.S. 658 (1978), was the first case to allow suits of this type.

5 See, e.g., Mastracchio v. Ricci, 498 F.2d 1257 (1st Cir. 1974), cert. denied, 420 U.S. 909 (1975); Clark v. Lutcher, 436 F. Supp. 1266, 1272 (M.D. Pa. 1977).

6 To date, the Supreme Court has not directly addressed the issue to what extent collateral estoppel applies in these cases. See Vestal, State Court Judgment as Preclusive in Section 1983 Litigation in a Federal Court, 27 Orra. L. Rev. 185, 191-92, 195-97 (1974); Comment, Res Judicata and Section 1983: The Effect of State Court Judgments on Federal Civil Rights Actions, 27 U.C.L.A. L. REv. 177, 180 \& n.10 (1979) [hereinafter cited as U.C.L.A. Comment].

A majority of circuits having considered the issue apparently would estop a state criminal defendant from relitigating his constitutional claim in a section 1983 proceeding. See, e.g., Winters v. Lavine, 574 F.2d 46, 58 (2d Cir. 1978); Martin 
The Eighth Circuit, however, recently ruled that collateral estoppel will not universally preclude relief in section 1983 cases. $^{7}$ In McCurry $v$. Allen, ${ }^{8}$ Willie McCurry filed a section 1983 action in federal district court seeking damages from several police officers who allegedly violated his constitutional rights, including his fourth-amendment right to be free from illegal searches and seizures. The alleged violations occurred during McCurry's arrest and the ensuing search of his home. McCurry had unsuccessfully litigated the fourth-amendment issue in the course of a pretrial suppression hearing and before the intermediate state appellate court ${ }^{9}$

v. Delcambre, 578 F.2d 1164, 1165 (5th Cir. 1978) (per curiam); Rimmer v. Fayetteville Police Dep't, 567 F.2d 273, 276 (4th Cir. 1977); Mastracchio v. Ricci, 498 F.2d 1257, 1260 (1st Cir. 1974), cert. denied, 420 U.S. 909 (1975); Thistlethwaite v. City of N.Y., 497 F.2d 339, 341-43 (2d Cir.), cert. denied, 419 U.S. 1093 (1974); Metros v. United States Dist. Ct., 441 F.2d 313 (10th Cir. 1970).

The Third Circuit purports to be in agreement with this view, see Kauffman v. Moss, 420 F.2d 1270, 1274 (3d Cir.), cert. denied, 400 U.S. 846 (1970), but the opinion labeled the "opinion of the court," id. 1271, is joined by only one judgethe second judge dissented in relevant part, id. 1277, and the third judge concurred only "in the result." Id. Further, one district court in the Third Circuit has reached the opposite result. See Clark v. Lutcher, 426 F. Supp. 1266 (M.D. Pa. 1977).

A proposed amendment to $\$ 1983$, the Civil Rights Improvements Act of 1979 , S. 1983, 96th Cong., Ist Sess., 125 Cong. Rec. S15,994 (daily ed. Nov. 6, 1979) [hereinafter cited as S. 1983], would accord prior state judgments only res-judicata, not collateral-estoppel, effect. Id. \$2. Further, the prior judgment would be binding only if that action had been initiated by the federal plaintiff. Id. See 125 Cong. Rec. S15,992 (daily ed. Nov. 6, 1979) (remarks of Sen. Mathias) [hereinafter cited as Mathias]. See generally id. S15,992-94; Civil Rights Improvements Act of 1977: Hearings on S. 35 Before the Subcomm. on the Constitution of the Senate Comm. on the Judiciary, 95th Cong., 2d Sess. (1978) (hearings on a similar bill that died in committee).

S. 1983 would substantively change much current civil-rights case law. See, e.g., notes 59, 77, 90 \& 194 infra.

7 Although the issue is far from clear, two other circuits apparently would also not grant collateral-estoppel effect to the prior state-court adjudication. See, e.g., Brubaker v. King, 505 F.2d 534 (7th Cir. 1974); Ney v. California, 439 F.2d 1285, 1288 (9th Cir. 1971) (dictum).

8466 F. Supp. 514 (E.D. Mo. 1978), rev'd, 606 F.2d 795 (8th Cir. 1979), cert. granted, 100 S. Ct. 1012 (1980).

${ }^{9}$ See State v. McCurry, 587 S.W.2d 337, 340 (Mo. Ct. App. 1979), aff'g No. 77-862 (Mo. Cir. Ct. 1978), application for transfer (appeal) denied, No. 62015 (Mo. Sup. Ct. May 1, 1980).

McCurry's fourth-amendment challenge stemmed from the search for and seizure of heroin that was subsequently used to secure his conviction for possession of a controlled substance. The seizure came about after an abortive undercover operation; several undercover agents visited McCurry at his home and attempted to make a heroin purchase. Rather than deal, McCurry shot at them, wounding two agents seriously. During the course of a search of McCurry's house following his surrender, the police found and seized the heroin. The Missouri Circuit Court and Court of Appeals justified part of the search under the plain-view doctrine, see Coolidge v. New Hampshire, 403 U.S. 443 (1971), and the exigent-circumstances exception to the warrant requirement. See McCurry v. Allen, 587 S.W.2d at 340-41. 
prior to seeking federal relief. The federal district court, in turn, granted the defendant-policemen's motion for summary judgment on the ground that the full litigation of the search-and-seizure issue in the state courts collaterally estopped McCurry from using section 1983 to relitigate in federal court the constitutionality of the search. ${ }^{10}$ It was this ruling that McCurry appealed to the Eighth Circuit.

The court of appeals agreed with McCurry. Although the court refused to decide the general question whether, in the context of section 1983 litigation, an estoppel should bar the relitigation of any constitutional issue decided against the plaintiff in the course of a prior state criminal trial, ${ }^{11}$ it did hold that no estoppel would apply to bar fourth-amendment claims. ${ }^{12}$ The unavailability of habeas-corpus relief for fourth-amendment violations was the determinative consideration; ${ }^{13}$ in the court's mind, the strong section 1983 policy of providing a federal forum for constitutional claims, combined with the recent removal of habeas as such a forum, outweighed any reasons for granting an estoppel. ${ }^{14}$ Thus, the Eighth Circuit reasoned that McCurry should be accorded access to a federal court to litigate his federal claims at least once; because habeas relief was not available to him, McCurry was permitted to seek relief under section 1983.

The Eighth Circuit's holding in McCurry was motivated by considerations transcending technical aspects of collateral estoppel; the reasoning relies heavily on unresolved questions of state- and federal-court relations. This Comment will analyze the McCurry result from the standpoint of federalism. First, the Comment will examine the premise that the federal courts have an obligation, embodied in section 1983, to hear federal constitutional claims, even should relitigation of findings previously made in the course of a state criminal proceeding be required. Second, the Comment explores the issue whether the availability of habeas relief ab-

10 McCurry v. Allen, 466 F. Supp. at 515-16.

11 McCurry v. Allen, 606 F.2d at 798.

12 Id. 798-99.

13 The lack of habeas relief for state convictions based on evidence seized in violation of the fourth amendment is a relatively new development in constitutional law. In Stone v. Powell, 428 U.S. 465 (1976), the Supreme Court put an abrupt end, in most cases, to the practice sanctioned at least since Kaufman v. United States, 394 U.S. 217 (1969), of entertaining such requests for habeas. Thus, a grant of certiorari to the Supreme Court, 28 U.S.C. $\$ 1257$ (3) (1976), remains as the only route for federal review of this type of fourth-amendment claim.

14 McCurry v. Allen, 606 F.2d at 799. 
solves federal courts of this obligation, ${ }^{15}$ and, if not, what other impact the availability or unavailability of habeas might have. Finally, the Comment will consider whether fourth-amendment claims merit a more lenient application of the collateral-estoppel doctrine. ${ }^{16}$

The Comment concludes that section 1983 does indeed embody a "federal-forum policy" that requires the federal courts to permit relitigation, unburdened by collateral estoppel, of issues previously litigated in some cases when a state criminal defendant seeks damages to compensate for the unconstitutional conduct of state lawenforcement officials. Further, the availability of federal habeascorpus relief should play no role in determining whether relief under section 1983 is eventually available; habeas does, however, impose constraints on the timing of section 1983 relief. The criterion that determines whether collateral estoppel should bar such suits is instead the ability of society to tolerate inconsistent adjudications of constitutional issues arising from official misconduct. Application of this test to the fourth-amendment issues of McCurry compels the conclusion that collateral estoppel should not bar the relitigation of the plaintiff's claims in any section 1983 action based on the fourth amendment. ${ }^{1 \tau}$

15 For cases suggesting that habeas may make a difference, see Rimmer $v$. Fayetteville Police Dep't, 567 F.2d 273, 276 (4th Cir. 1977); Meadows v. Evans, 550 F.2d 345, 345-46 (5th Cir.) (per curiam) (Goldberg, J., dissenting in part), cert. denied, 434 U.S. 969 (1977); Ford v. Byrd, 544 F.2d 194, 195 n.2 (5th Cir. 1976); Brazzelli v. Adams, 493 F.2d 489, 490 (5th Cir. 1974); Clark v. Lutcher, 436 F. Supp. 1266, 1272 (M.D. Pa. 1977); Moran v. Mitchell, 354 F. Supp. 86, 88-89 (E.D. Va. 1973).

16 See generally Averitt, Federal Section 1983 Actions after State Court Judgment, 44 U. CoLo. L. REv. I91 (1972); McCormack, Federalism and Section 1983: Limitations on Judicial Enforcement of Constitutional Claims, (pt. 2), 60 VA. L. Rev. 250 (1974); Theis, Res Judicata in Civil Rights Act Cases: An Introduction to the Problem, 70 Nw. U.L. Rev. 859 (1976); Vestal, Res Judicata and Section 1983: The Effect of State Court Judgments on Federal Civil Rights Actions, 65 Iowa L. REv. 281 (1980); Vestal, supra note 6; Section 1983 Developments, supra note 3, at 1330-60; UCLA Comment, supra note 6; Note, The Collateral Estoppel Effect of State Criminal Convictions in Section 1983 Actions, 1975 U. Irr. L.F. 95 [hereinafter cited as Irc. Note].

17 It is important at the outset to note the narrow approach of this Comment. The Comment does not discuss the use of $\$ 1983$ as a vehicle for mounting a collateral attack on any state civil, see, e.g., Huffman v. Pursue, Ltd., 420 U.S. 592 (1975), or criminal, see, e.g., Waste Management, Inc. v. Fokakis, 614 F.2d 138 (7th Cir. 1980), petition for cert. filed, 48 U.S.L.W. 3716 (U.S. Apr. 23, 1980) (No. 79-1679), judgment. Such attempts are properly precluded on either jurisdictional, see, e.g., id., or res-judicata, see, e.g., Diaz-Buxo v. Trias Monge, 593 F.2d 153 (1st Cir. 1979), grounds.

In contrast, in the factual scenario examined in this Comment, the state-court judgment is not directly attacked. Compare Waste Management, Inc. v. Fokakis, 614 F.2d 138 (7th Cir. 1980), petition for cert. filed, 48 U.S.I.W. 3716 (U.S. Apr. 23, 1980) (No. 79-1679) (defendant-corporation convicted and fined in a state criminal proceeding attempted to use $\S 1983$ as a means of directly attacking 


\section{INTroduction to the LAW of Collateral EstopPel}

Before considering the federalism issues that are the primary focus of this Comment, a summary of the technical aspects of collateral estoppel is necessary to demonstrate that, other considerations aside, McCurry would be estopped from relitigating the adverse determination of his fourth-amendment claim. ${ }^{18}$

The doctrine of collateral estoppel, or issue preclusion, makes the prior determination of an issue binding on a party or his privy in a subsequent proceeding. ${ }^{19}$ Four conditions must be satisfied in order to estop the relitigation of a previously decided issue. First, there must be substantial identity of issues; the issue sought to be relitigated must be essentially the same as the issue litigated in the previous action. ${ }^{20}$ Second, this issue must have been actually litigated in the prior action. ${ }^{21}$ Third, there must have

conviction in federal court) with Brubaker v. King, 505 F.2d 534 (7th Cir. 1974) ( $\$ 1983$ plaintiff sought damages for arrest without probable cause after state magistrate had found probable cause and state criminal proceeding then had been dismissed on state's motion).

18 This Comment shall subsequently demonstrate, however, that collateral estoppel is not an inflexible doctrine. Once the key "other consideration"-federalism policies-is added to the equation, the conclusion is reached that collateral estoppel should be no inherent bar to $\$ 1983$ damage suits arising out of a state criminal proceeding no matter what the constitutional violation being claimed. This conclusion, however, is only a beginning; succeeding observations suggest a narrowing of the relief available.

19 See generally, F. James \& G. HAZARD, Crvm Procedure \$\$ 11.16-.31 (2d ed. 1977) [hereinafter cited as F. JAMes]; 1B J. Moore \& T. Curruer, Moore's Federat Practice IT 0.441-.448 (2d ed. 1974 \& Supp. 1979-80) [hereinafter cited as J. Moore]; Restatement (Second) of Judgmen'ss, topic 2, $\$ \$ 68$, 68.I (Tent. Draft No. 4, 1977) [hereinafter cited as REstatement]; Currie, Res Judicata: The Neglected Defense, 45 U. CHr. L. Rev. 317 (1978); Developments in the Law-Res Judicata, 65 HARv. L. REv. 818 (1952).

20 E.g., Montana v. United States, 440 U.S. 147, 155-58 (1979); Scooper Dooper, Inc. v. Kraftco Corp., 494 F.2d 840, 844 (3d Cir. 1974); J. Moone, supra note 19, at If 0.443[2]; Restatement, supra note 19, at $\$ 68$, Comment c.

Lower federal courts considering $\$ 1983$ claims have often required an "identity" of issues, a requirement that sometimes appears to be a subterfuge for considering meritorious claims that might otherwise be barred by collateral esoppel. See, e.g., Brubaker v. King, 505 F.2d 534 (7th Cir. 1974) (issue of constitutionality of police conduct not identical to issue of good-faith belief in existence of probable cause); Williams v. Liberty, 461 F.2d 325, 327 (7th Cir. 1972) (issue of existence of probable cause for arrest not identical to issue of excessiveness of force employed in effecting arrest). The Brubaker distinction is incorrect, see McCurry v. Allen, 606 F.2d 795, 798 n.10 (8th Cir. 1979), cert. granted, 100 S. Ct. 1012 (1980), because a finding that the police conduct in question is constitutional comprises a complete defense to a $\$ 1983$ claim. The Williams distinction is sounder, as an excessively violent arrest may be justified by probable cause and yet still be "unreasonable" under the fourth amendment.

21 E.g., Fernandez v. Trias Monge, 586 F.2d 848, 856 (1st Cir. 1978); Jackson v. Official Reps. \& Employees of the L.A. Police Dep't, 487 F.2d 885, 886 (9th Cir. 1973); F. JAגIss, supra note 19 , at $\$ 11.17$; J. Moore, supra note 19, at โ0.443[3]; Restatement, supta note 19, at $\$ 68$, Comments d \& e; Vestal, supra note 6, at 208-09. But see Metros v. United States Dist. Ct., 441 F.2d 313 (1970) 
been a determination in the first action precisely on this issue. ${ }^{22}$ Finally, this determination must have been necessary to the judgment in the earlier action. ${ }^{23}$

Collateral estoppel should be distinguished from its parent doctrine-res judicata. ${ }^{24}$ Although both doctrines serve many of the same societal interests, ${ }^{25}$ the scope of collateral estoppel is different from that of res judicata. Res judicata totally bars the relitigation of whole causes of actions; the effect of collateral estoppel is limited to individual facts ${ }^{26}$ or issues. ${ }^{27}$ Ironically, the scope of collateral estoppel is both broader and narrower than that of its parent doctrine. Collateral estoppel sweeps further than res judicata in that its application is not restricted to later suits between the same parties and their privies; only the party against whom the doctrine is invoked must have been present or represented in the prior action. ${ }^{28}$ At the same time, the effect of res judicata

(collateral estoppel by guilty plea); Palma v. Powers, 295 F. Supp. 924, 937 (N.D. III. 1969) (collateral estoppel barred $\$ 1983$ claim despite fact that constitutional question was never litigated at trial-" "[u]nder these circumstances, his failure to contest the issue can reasonably be regarded as an admission. . . .").

22 E.g., Montana v. United States, 440 U.S. 147, 153 (1979); Fernandez v. Trias Monge, 586 F.2d 848, 857 (1st Cir. 1978); F. JAMEs, supra note 19, at $\S 11.18$.

23 E.g., Montana v. United States, 440 U.S. 147, 153 (1979); Winters v. Lavine, 574 F.2d 46, 57 (2d Cir. 1978); Parker v. McKeithen, 488 F.2d 553, 558 (5th Cir.) (quoting Hyman v. Regenstein, 258 F.2d 502, 511 (5th Cir. 1958), cert. denied, 359 U.S. 913 (1959)) cert. denied, 419 U.S. 838 (1974); F. JAMES, supra note 19, at $\$ 11.19$; J. Moore, supra note 19, at If 0.443[5]; REsTATEMENT, supra note 19 , at $\$ 68$, Comment $\mathrm{h}$.

24 See J. MoORE, supra note 19, at IT 0.405[3] \& 0.441[1]. See generally F. JAMES, supra note 19, at $\$$ 11.3-.15.

25 For example, both collateral estoppel and res judicata encourage efficient use of judicial resources, enhance predictability and consistency, and foster respect for determinations of the original tribunal. See F. JAires, supra note 19, at $\$ 11.2$; In. Note, supra note 16 , at 96.

${ }^{26} \mathrm{~A}$ distinction is sometimes drawn between issues of fact or mixed law/fact, and issues of law. Collateral-estoppel effect can be accorded only to questions of pure fact or mixed law/fact. Yates v. United States, 354 U.S. 298, 336 (1957). Determinations of law have primarily precedential value. See J. MOORE, supra note 19 , at $\llbracket 0.442$ [1]. But see F. JAMES, supra note 19 , at $\$ 11.20$ (collateral estoppel once had only precedential value, but modern trend is to apply issue preclusion to legal issues, subject to special qualifications ).

27 See J. MOORE, supra note 19, at $10.405[1]$. Thus, denying collateralestoppel effect to a prior factual determination does not threaten a judgment to the same extent as the relitigation of an entire claim.

28 This has not always been the case. Until recently, the doctrine of mutuality limited the application of collateral estoppel. See Comment, Collateral Estoppel: The Changing Role of the Rule of Mutuality, 41 Mo. L. Rev. 521 (1976) [hereinafter cited as Mo. Comment]. The mutuality doctrine prevented any party from benefiting from an estoppel unless he could also be burdened by it. J. Moore, supra note 19 , at $\mathbb{\int} 0.412$ [1]. Because due process required that an individual not party or privy to a prior action could never be burdened by an estoppel arising therefrom, see, e.g., Hansberry v. Lee, 311 U.S. 32, 40-41 (1940); Mo. Com- 
is more extensive than that of collateral estoppel ${ }^{29}$ in that the former doctrine may be applied to bar causes of action that could have been, but were not, litigated in the prior action; ${ }^{30}$ the four prerequisites for the application of collateral estoppel are not apposite. $^{31}$

These distinctions make clear that collateral estoppel, and not res judicata, is the correct doctrine to apply to section 1983 damage claims based on issues previously litigated in state criminal proceedings. The basic requirements of res judicata are not met in such cases. First, the parties in the section 1983 suit are not the same as the parties in the state criminal action. For example, McCurry, of course, was present in both proceedings, but his adversary in each action was different. ${ }^{32}$ Second, the civil cause of action is quite different from the criminal one, thus independently defeating the use of res judicata. ${ }^{33}$

ment, supra, at 524, the mutuality doctrine effectively limited the scope of collateral estoppel to situations where the parties in the second action were either opposing parties, or in privity with the opposing parties, in the former action.

Most state and federal courts, however, have relaxed the mutuality requirement, at least where the nonparty is using the estoppel defensively in the later suit. See, e.g., Blonder-Tongue Labs., Inc. v. University of Mll. Foundation, 402 U.S. 313, 328-30 (1971); Bernhard v. Bank of America, 19 Cal. 2d 807, 122 P.2d 892 (1942); Mo. Comment, supra, at 526-27. Although at least one commentator has suggested that a $\mathrm{McC}$ urry-type suit might be an appropriate context in which to revive the mutuality requirement, see McCormack, supra note 16 , at 289-90, the federal courts have not agreed. See, e.g., Mastracchio v. Ricci, 498 F.2d 1257, 1260 (1st Cir. 1974), cert. denied, 420 U.S. 909 (1975).

29 The narrowness of the scope of collateral estoppel exists because too broad an application may yield "unforeseeable and sometimes unjust results." J. Moore, supra note 10 , at $\int 0.441$ [2].

30 See Flynn v. State Bd. of Chiropractic Examiners, 418 F.2d 668 (9th Cir. 1969); Restatenent, supra note 19, at $\$ \$ 61-61.1$ (Tent Draft No. 1, 1973). But see England v. Louisiana State Bd. of Medical Examiners, 375 U.S. 411 (1964).

31 See notes 20-23 supra \& accompanying text.

32 The police officers were, at most, only witnesses in the criminal proceeding. It could be argued, however, that, because the state is significantly involved in prosecuting the case, the requirements of privity are met. See Montana v. United States, 440 U.S. 147, $154 \&$ n.5 (1979); J. MOORE, supra note 19, at $\{0.411[6]$. Although this argument, if accepted, meets the identity-of-parties requirement, the second deficiency-a lack of identity between causes of action-would still defeat any attempt to apply res judicata. See note 33 infra \& accompanying text.

${ }^{33}$ Modern thinking defines a cause of action in terms of a given transaction or operative set of facts without regard to the legal theory under which suit is brought or to the remedy requested. See New Jersey Educ. Ass'n v. Burke, 579 F.2d 764, 774 n.53 (3d Cir.), cert. denied, 439 U.S. 894 (1978); Restatement, supta note 19 , at $\$ 61$, Comment a. A $\$ 1983$ suit is a different action than the claim litigated in a suppression hearing, for example, because the damage relief available in the $\$ 1983$ suit is not available in a criminal proceeding. Further, courts still adhere to the principle that civil and criminal proceedings by their very nature involve different causes of action. See, e.g., Fernandez v. Trias Monge, 586 F.2d 848, 856 n.11 (1st Cir. 1978); J. MOORE, supra note 19, at $\mathbb{1}$ 0.418[1]. 
On the other hand, in a case such as McCurry, in which an issue crucial ${ }^{34}$ to the section 1983 constitutional claim was raised and defeated in the course of a criminal trial, the technical requirements of collateral estoppel generally are met. First, the substantialidentity-of-issues requirement is met in $M c$ Curry-the lack of probable cause, the issue decided against McGurry in the suppression hearing, was the basis of his section 1983 suit. 35 Second, the constitutionality of the search and seizure was both fully litigated and decided ${ }^{36}$ for estoppel purposes. Finally, because the heroin McCurry attempted to suppress was the only evidence offered against him by the state to prove possession, the finding of probable cause was evidently necessary to the judgment. ${ }^{37}$

34 Crucial issues are of a different form depending on the nature and context of the constitutional claim. A fourth-amendment question, for example, is litigated in a suppression hearing ancillary to the regular trial. The claim asserted in the suppression hearing is that the search or arrest was without probable cause.

The issue estopped here thus would be the specific finding of probable cause. The federal determination whether to estop relitigation of that issue would require a detailed examination of the state record to determine the extent of consideration. See, e.g., Kauffman v. Moss, 420 F.2d 1270, $1274-75$ (3d Cir.), cert. denied, 400 U.S. 846 (1970). This is a somewhat uncertain undertaking, however, as it is usually difficult to determine what evidentiary facts were necessary to the prior determination given the normally informal nature of the earlier proceeding. See note 23 supra \& accompanying text.

A second type of constitutional question involves the determination of the voluntariness of a confession. This issue is normally resolved at a special hearing prior to trial. If the court rules that the confession is not involuntary as a matter of law, the defendant still may argue voluntariness to the jury. An allegation of perjury by a state official is a similar recurring theme. Here, most commonly, no constitutional claim would be raised at trial. Instead, the jury must itself judge the credibility of each witness.

When courts employ collateral estoppel to block litigation in both these situations, the theory is that the jury must have believed that the confession was voluntary or that the witness was reliable in order to arrive at its guilty verdict. See note 23 supra \& accompanying text. This assumption is somewhat dubious because it is difficult to determine why juries decide cases as they do. See United States v. Standefer, 610 F.2d 1076, 1095 (3d Cir. 1979) (en banc), aff'd, 100 S. Ct. 1999 (1980).

35 This need not always be the case, however. See note 20 supra.

36 See note 9 supra \& accompanying text.

37 This matter may not always be so clear, depending on exactly what is considered to be the "judgment." If the judgment is the finding of probable cause in the suppression hearing, for example, then the constitutional issue and the judgment are identical and, as a matter of logic, the determination of the constitutional issue was necessary to reach the judgment. Even so, this scenario should not always lead to federal court application of collateral-estoppel doctrine. Should a defendant lose on the issue of probable cause in a suppression hearing, but be found not guilty at trial, he should not be collaterally estopped from contesting the constitutionality of the police conduct in a $\$ 1983$ suit, because he cannot appeal the suppression hearing finding. See Wilkinson v. Ellis, 484 F. Supp. 1072, 1087 (E.D. Pa. 1980) (quoting Jones v. Saunders, 422 F. Supp. 1054, 1055 (E.D. Pa. 1976)).

If, on the other hand, the judgment is considered to be the guilty verdict, it is often difficult to know exactly what issues the trier of fact found necessary, 
Thus, the technical requirements of collateral estoppel appear to be satisfied and a section 1983 plaintiff in a position similar to McCurry's would be precluded from relitigating his claim. But these technical requirements do not operate in a vacuum; the doctrine of issue preclusion is somewhat flexible ${ }^{38}$ depending on the degree to which policy considerations transcending those of finality are implicated, and, sub silentio, the apparent merit of the claim or defense sought to be estopped. Federal courts have relied on this flexibility extensively to rescue potentially meritorious section 1983 claims from the effects of issue preclusion. ${ }^{39}$ On the other hand, when presented with a clearly unmeritorious claim, ${ }^{40}$ these same courts have either avoided hypertechnical application of the doctrine's criteria, or excused them altogether, ${ }^{41}$ in order to grant preclusive effect to state determinations.

An analysis of both sets of cases reveals that the technical requirements for the use of collateral estoppel are often overshadowed by other concerns, especially federalism considerations. ${ }^{42}$ Such an

absent specific findings. See, e.g., Thistlethwaite v. City of N.Y., 497 F.2d 339, 342 (2d Cir.), cert. denied, 419 U.S. 1093 (1974). This problem is especially likely to arise in $\$ 1983$ suits involving claims such as perjury by state officials. See note 34 supra.

38 See generally J. Moore, supra note 19, at fโ 0.405[12], 0.44I[2].

39 Federal courts have relied on a number of technical arguments to avoid dismissing such claims including the nonidentity of issues, see note 20 supra, the differing preclusive effect of law versus fact, see note 26 supra, the nonessentialness of the issue to the final judgment, see, e.g., Williams v. Liberty, 461 F.2d 325, 327-28 (7th Cir. 1972), and the lack of a possibility of appeal, see, e.g., Wilkinson v. Ellis, 484 F. Supp. 1072, 1087-88 (E.D. Pa. 1980); cf. F. JAMES, supra note 19, at $\$ 11.20$ (estoppel not applied to legal issues if prior case not fully appealed).

40 See, e.g., Nash v. Reedel, 86 F.R.D. 13 (E.D. Pa. 1980), appeal dismissed as frivolous, No. 80-1331 (3d Cir. May 22, 1980) (petition for rehearing pending). See also note 34 supra. In Nash, a convicted two-time rapist brought a $\$ 1983$ action against his victims for alleged perjury, and against the local police for, inter alia, knowing use of the allegedly perjured testimony of the victims. Following an examination of the state trial record, Judge Luongo held the rapist estopped from litigating the truth of the testimony, concluding that the state judge must have found the testimony true in order to convict.

41 See Metros v. United States Dist. Ct., 441 F.2d 313 (10th Cir. 1970), in which the court held that a guilty plea precluded litigation under $\$ 1983$ of a fourth-amendment search-and-seizure issue which, had it been litigated successfully, would have resulted in the suppression of crucial evidence. Not all federal judges are comfortable with this result. See, e.g., Meadows v. Evans, 550 F.2d 345, 345 (5th Cir.) (Goldberg, J., dissenting in part from en banc, per curiam opinion), cert. denied, 434 U.S. 969 (1977); Metros v. United States Dist. Ct., 441 F.2d at 318-19 (Holloway, $J .$, concurring in the result).

42 Some courts admit as much. See, e.g., Fernandez v. Trias Monge, 586 F.2d 848, $856 \mathrm{n.11}$ (1st Cir. 1978) ("Especially when federalism interests are involved, modern analysis has tended away from the technicalities in favor of analysis of the purposes of issue and claim preclusion." (citing Currie, supra note 20, at 341-42)); Meadows v. Evans, 550 F.2d 345, 345 (5th Cir.) (Goldberg, J., dissenting in part from en banc, per curiam opinion) ("IT]he rigors that are conditions precedent to 
ad hoc application of the doctrine of collateral estoppel is not satisfactory; some articulation of the considerations that lie behind these differing results is the next task of this Comment.

\section{Federalism and the Application of Collateral Estoppex in Section 1983 Actions}

That a plaintiff in McCurry's position is questioning a state determination in federal court necessarily raises the issue of federalstate relations. But there are federalism considerations that argue both for and against according collateral-estoppel effect in a McCurry-type suit. ${ }^{43}$

\section{A. Section 1738}

Those tending to support estoppel mirror the policies discussed above.44 For example, the Full Faith and Gredit Act ("Section $\left.1738^{\prime \prime}\right)^{45}$ is a statutory embodiment of the policy that due deference is owed to the prior determinations of a state court. ${ }^{46}$ A broad reading of section 1738 would preclude relitigation of any issue decided in state court if the state's own courts would themselves bar relitigation.47 It would, however, be unwise to construe the statute so broadly. It was not at all foreseeable to its draftsmen that section 1738 would ever be invoked, for example, to force a federal court to give collateral-estoppel effect to a state court determination in these circumstances. ${ }^{48}$

the application of collateral estoppel generally must be scrupulously observed in this context of state prisoner $\$ 1983$ claims."), cert. denied, 434 U.S. 369 (1977). 43 McCurry v. Allen, 606 F.2d 795 (8th Cir. 1979), cert. granted, 100 S. Ct. 1012 (1980).

44 See note 25 supra and accompanying text.

4528 U.S.C. $\$ 1738$ (1976).

46 "[J]udicial proceedings . . . shall have the same full faith and credit in every court within the United States and its Territories and Possessions as they have by law or usage in the courts of such state ... from which they are taken." Id.

${ }^{47}$ See, e.g., American Mannex Corp. v. Rozands, 462 F.2d 688, 690 (5th Cir.) (dictum), cert. denied, 409 U.S. 1040 (1972); Section 1983 Developments, supra note 3 , at 1338 n.37.

At least one court has suggested that $\$ 1738$ does not require that collateralestoppel effect be given to state-court-determined facts in actions falling within exclusive federal jurisdiction. See Lyons v. Westinghouse Elec. Corp., 222 F.2d 184, 189-90 (2d Cir.), cert. denied, 350 U.S. 825 (1955); Section 1983 Developments, supra note 3, at 1334-35. Although $\$ 1983$ jurisdiction is concurrent, see, e.g., Brown v. Pitchess, 13 Cal. 3d 518, 523, 531 P.2d 772, 775, 119 Cal. Rptr. 204,207 (1975); Theis, supra note 20 , at $860 \mathrm{n} .10$, it is likely that the draftsmen of the statute foresaw that jurisdiction would, in practical effect, be exclusive, because a litigant would be unlikely to risk challenging a state in its own courts. But see Vestal, supra note 6, at 210.

48 The law of collateral estoppel was not well developed at the time. The relevant part of $\$ 1738$ is based on the Act of May 26, 1790, ch. XI, 1 Stat. 122, 
The most obvious application of section 1738 is to final judgments; to the extent that the state judgment itself is not collaterally attacked or impeached, the justification for a broad interpretation of section 1738 is that much weaker. ${ }^{49}$ In the McCurry paradigm, no final judgment need be disturbed; the guilty verdict is not directly attacked by a section 1983 action. Although inconsistent adjudication may cause the state verdict to appear manifestly unjustifiable, 50 this need not be the case. It could be maintained that the result of the suppression hearing is a final judgment entitled to "protection" under section 1738.51 But the state's interest in preserving the integrity of this "judgment," often informally decided and not necessarily having any direct relevance to the guilt of the defendant, is of an entirely different magnitude than the state's interest in a final verdict. These considerations limiting the application of section 1738 become even more compelling when the federal-forum policy imbedded in section 1983 is considered.52

Thus, section 1738 should not be interpreted broadly in this context. Federal courts should not hide behind the cloak of section 1738 to avoid principled decisions concerning this difficult aspect of federal-state relations. ${ }^{53}$

and survives with only nominal changes. The mutuality requirement, which would otherwise bar the use of collateral estoppel by the police-defendants in a McCurrytype suit, did not begin to erode until 1942. See note 28 supra. See also Section 1983 Developments, supra note 3, at 1339 n.39.

49 See Section 1983 Developments, supra note 3, at 1338-39. Section 1738 might be best viewed as a broad way to prevent state actions from "indiscriminate collateral attack" through the federal courts. See Averitt, supra note 16, at 203. A narrow exception designed to facilitate actions under $\S 1983$ would do little to compromise this protection. Further, it is unclear whether a state court would accord deference to its own findings if a $\$ 1983$ suit were brought before it. To the extent that federal courts are unclear on this point, they should err on the side of vindication of federal rights. See Averitt, supra note 16, at 203; Theis, supra note 16 , at 876 .

50 This is particularly likely to be true when the constitutionality of a state statute under which a criminal conviction was obtained is later challenged in federal court. See, e.g., Thistlethwaite v. City of N.Y., 497 F.2d 339 (2d Cir.), cert. denied, 419 U.S. 1093 (1974).

51 See note 19 supra.

62 See text accompanying notes 80-110 infra.

53 Compare Winters v. Lavine, 474 F.2d 46, 55 (2d Cir. 1978) (unlike most suits, preclusion in federal civil-rights suits is controlled by federal common law, rather than by $\$ 1738$ and state law) and Ohland v. City of Montpelier, $467 \mathrm{~F}$. Supp. 324, 336-37 (D. Vt. 1979) (rule giving collateral-estoppel effect to state administrative fact finding is "not to be applied mechanically" Id. 337) with Omernick v. LaRoucque, 406 F. Supp. 1156,1159 (W.D. Wis.) ( $\$ 1738$ requires federal court to apply state res-judicata rule in $\$ 1983$ suit), aff'd mem., 539 F.2d 715 (7th Cir. 1976).

In a recent statement on collateral estoppel, the Supreme Court made no reference to $\$ 1738$ in concluding that, on the facts of that case, collateral estoppel barred relitigation in federal court of a constitutional issue previously decided in 


\section{B. Comity}

Regardless of the relevance or outcome of the application of section 1738, a federal court could exercise its discretion and apply the federal common law of collateral estoppel ${ }^{54}$ to preclude relitigation of an issue previously litigated at the state level.55 Comity-" $[t]$ he principle in accordance with which the courts of one ... jurisdiction will give effect to the laws and judicial decisions of another, not as a matter of obligation, but out of deference and respect" 56 -has special relevance in the federal system.

Comity finds its foremost expression in Younger $v$. Harris, ${ }^{57}$ in which the Supreme Court held that federal courts, as a discretionary matter, may not enjoin an ongoing state criminal prosecution absent extraordinary circumstances. ${ }^{58}$ Younger and its progeny ${ }^{59}$ however, are not directly applicable to the concerns of

state court. Montana v. United States, 440 U.S. 147 (1979). Of course, because federal common law was sufficient to justify the preclusion, the case has no precedential value for the proposition that $\$ 1738$ has no applicability to collateral estoppel.

For an excellent discussion of the applicability of $\$ 1738$ in $\$ 1983$ analysis, see Section 1983 Developments, supra note 3, at 1331.

$5 \pm$ For centerpiece cases on the "federal common law of collateral estoppel," see Montana v. United States, 440 U.S. 147 (1979); Blonder-Tongue Labs., Inc. v. University of Ill. Foundation, 402 U.S. 313 (1971); Cromwell v. County of Sac., 94 U.S. 351 (1877).

55 Winters v. Lavine, 574 F.2d 46, 55 (2d Cir. 1978).

56 Black's LaW Dictionary 242 (5th ed. 1979).

57401 U.S. 37 (1971).

58 Id. 53-54.

59 Younger and its progeny-the Younger-abstention cases-consider a series of issues: (I) what constitutes interference, e.g., Younger v. Harris, 401 U.S. at 43-53 (enjoining state proceeding); Samuels v. Mackell, 401 U.S. 66, 73 (1971) (declaratory judgment ordinarily has same practical effect as injunction). But see, e.g., Moore v. Sims, 442 U.S. 415, 431 (1979) (injunction to hold state pretrial proceeding is not interference with state prosecution itself) (quoting Gerstein v. Pugh, 420 U.S. 103, 108 n.9 (1975)). Cf. id. (although federal court may not enjoin ongoing state custody proceeding, Court raised no objection to federal pretrial order placing children in parents' custody); (2) the type of state proceeding with which interference is barred, e.g., Moore v. Sims, 442 U.S. at 434-35 (stateinitiated child-custody suit); Trainor v. Hernandez, 431 U.S. 434, 444 (1977) (civil proceeding by state to recover fraudulently obtained welfare payments); Juidice v. Vail, 430 U.S. 327,335 (1977) (civil-contempt proceeding in private civil suit); Huffman v. Pursue, Ltd., 420 U.S. 592, 606-07 (1975) (nuisance proceeding against pornographic-movie theater); Younger v. Harris, 401 U.S. at 53 (state criminal prosecution); and (3) when a federal court may not interfere, e.g., Hicks v. Miranda, 422 U.S. 332,349 (1975) (requiring dismissal of federal suit if state proceedings commence "before any proceedings of substance on the merits have taken place in federal court"). But see Doran v. Salem Inn, Inc., 422 U.S. 922, 928-30 (1975) (federal court may enjoin threatened prosecution); Steffel v. Thompson, 415 U.S. 452, 472-73 (1974) (federal court can declare unconstitutional state law under which prosecution is threatened). See generally Comment, PostYounger Excesses in the Doctrine of Equitable Restraint: A Critical Analysis, 1976 DUkE L.J. 523 [hereinafter cited as DukE Comment]. 
this Comment; their emphasis is clearly on interference with state proceedings. Because a suit for damages under section 1983, appropriately timed, ${ }^{60}$ need not interfere with any ongoing or imminent state proceeding, it would be a mistake to apply mechanically the comity doctrine of Younger. "The issue of whether federal courts should be able to interfere with ongoing state proceedings is quite distinct and separate from the issue of whether litigants are entitled to subsequent federal review of state-court dispositions of federal questions." 61

Although federal case law accords the states some comity interest in their determinations of federal constitutional issues, ${ }^{62}$ the scope of this interest is not certain. On the one hand, for determinations implicating mostly federal law, the degree of deference due appears low. For example, federal questions are subject to review and correction by the Supreme Court through direct or certiorari review, ${ }^{63}$ and, occasionally, by the lower federal courts. ${ }^{64}$ When federal courts have invoked comity, the protected interest has tended to be the orderly administration of concurrent state proceedings, and not the integrity of the determination itself. ${ }^{65}$ In this

Despite the lack of ongoing state proceedings, Younger-type considerations have been invoked as limits on the equitable powers of federal courts in civil-rights cases. See, e.g., Rizzo v. Goode, 423 U.S. 362, 377-80 (1976).

The proposed Civil Rights Improvements Act would restrict the Younger doctrine in $\$ 1983$ suits. See S. 1983, supra note 6, at $\$ 2$ (proposed 42 U.S.C. $\$ \$ 1983(\mathrm{c})(2),(\mathrm{e})(3)-(5))$. See generally Mathias, supra note 6, at S15,993-94.

The breadth of the bill's proposed reforms demonstrates the extent of the dissatisfaction with the Younger doctrine. The bill would: (1) overrule Moore 0 . Sims, Trainor v. Hernandez, and Huffman v. Pursue, Ltd. by limiting Younger abstention to criminal proceedings, see proposed $\$ 1983(\mathrm{e})(5) ;(2)$ overrule Hicks v. Miranda by allowing injunctions of state criminal proceedings commenced after the $\$ 1983$ action was filed, see proposed $\$ 1983(\mathrm{e})(4) ;(3)$ broaden the scope of exceptions to Younger to allow enforcement of injunction of statutes that are in part facially unconstitutional, compare proposed $\$ 1983(\mathrm{e})(3)$ with Younger v. Harris, 401 U.S. at 53-54 (federal court may enjoin enforcement of statute that is " $\mathrm{Hla}$ grantly and patently violative of express constitutional prohibitions in every clause, sentence and paragraph, and in whatever manner and against whomever an effort might be made to apply it") (quoting Watson v. Buck, 313 U.S. 387,402 (1941)); and (4) overrule Rizzo $v$. Goode by requiring broad injunctions against states and municipalities to prevent recurrence of constitutional violations, see proposed $1983(\mathrm{c})(2)$.

60 See text accompanying notes 126-58 infra.

B1 Huffman v. Pursue, Ltd., 420 U.S. 592, 606 (1975).

62 See, e.g., Montana v. United States, 440 U.S. 147, 163 (1979) ("Considerations of comity as well as repose militate against redetermination of issues in a federal forum at the behest of a plaintiff who has chosen to litigate them in state court.").

8328 U.S.C. $\$ 1257$ (1976).

64 Fay v. Noia, 372 U.S. 391 (1963); 28 U.S.C. $\$ 2254$ (1976) (habeas corpus).

65 See, e.g., Meadows v. Evans, 550 F.2d 345, 345 (5th Cir.) (en banc) (per curiam) (abstaining, rather than dismissing, claims requiring exhaustion of state post-conviction remedies), cert. denied, 434 U.S. 969 (1977). Accord, Meadows v. 
manner, states are given the opportunity to correct their own constitutional errors, but once this opportunity has been taken, and all appellate rights have been exhausted, the state-court determination of the federal question is open for review by the federal courts.

On the other hand, state-court determinations of historical facts present different considerations. In this area, no court has any special competence over any other; such findings are seldom reviewable on appeal to the Supreme Court and are subject to only limited review in federal habeas-corpus proceedings. ${ }^{66}$ A state court, thus, has a considerably greater comity interest in its determinations of fact than its rather minimal comity interest in the integrity of its determinations of issues inextricably intertwined with federal law.

Aside from the differences in the importance of the comity interest depending on whether the state-court determination is grounded in historical fact or federal law, a state has a greater comity interest to the extent that relitigation of an issue implicates the integrity of a judgment. If, for example, the disputed issue is the constitutionality of a state statute on which a criminal conviction rests, ${ }^{87}$ the state comity interest is quite strong. After all, the conviction itself is subject to collateral attack only through the extraordinary habeas-corpus remedy. Of course, there are many issues the relitigation of which will not implicate the state judgment ${ }^{88}$ and therefore this basis for comity depends on the nature of the constitutional right violated.

The recent Supreme Court case of Montana $v$. United States, ${ }^{69}$ concerning the preclusive effect of a state-court determination on a federal court, provides some insight on the proper scope of the comity interest for issues implicating state-court judgments. The Supreme Court held that, on the facts of Montana," "[c]onsidera-

Gabriel, 563 F.2d 1231 (5th Cir. 1977) (once plaintiff has exhausted state postconviction remedies, he may proceed with $\$ 1983$ suit).

66 See Townsend v. Sain, 372 U.S. 293 (1963); 28 U.S.C. $\$ 2254$ (d) (1976).

${ }^{67}$ See, e.g., Thistlethwaite v. City of N.Y., 497 F.2d 339 (2d Cir.), cert. denied, 419 U.S. 1093 (1974).

68 Further, the analytic emphasis should be on the essential justice of the verdict, not simply the existence of a but-for relation between the issue and the final result. For example, in the case of a probable-cause hearing, it is insufficient to find that had the judge decided the issue the other way, the evidence would have been excluded and the conviction unobtainable. Rather, the soundness of the verdict should be examined. See notes 165-74 infra \& accompanying text.

69440 U.S. 147 (1979).

70 In Montana, a private contractor brought suit in state court alleging the federal unconstitutionality of a state taxing provision. The United States government directed and financed the litigation. The state supreme court held against the plaintiff on all constitutional questions. 
tions of comity as well as repose militate against redetermination of issues in a federal forum" 71 and hence full collateral-estoppel effect was given. Montana involved a situation in which a reversal on the issue sought to be estopped would have totally discredited a statecourt judgment. ${ }^{72}$ There, the state's comity interest was significant, even though the disputed issue was intimately tied to federal law. No such strength of interest is necessarily present in McCurry-type suits and thus comity need not be a determinative concern in that context. ${ }^{33}$ Further, in Montana, unlike McCurry-type suits, the federal plaintiff initiated the state litigation, choosing a state over a federal forum. The Montana-type plaintiff thus has less reason to override the state's comity interest.

There is an affirmative justification for giving little weight to the state comity interest when a plaintiff is seeking damages from a state official for the violation of his constitutional rights. An official defending against a claim for damages is entitled to assert at least a qualified immunity that significantly restricts his liability. ${ }^{74}$ The availability of such an immunity, which must be

Subsequently, the United States brought an action in federal district court alleging similar constitutional infirmities. The question of the collateral-estoppel effect of the state supreme court's prior judgment naturally arose. Id. 163 . Although the government was not technically a party to the state action, the Court found that its activity was sufficient to bind the United States to the results of the proceeding. Id. $154-55,154$ n.5.

71 Id. 163.

72 On a functional level, Montana verges infinitesimally close to a question of res judicata-the only reason it was not analyzed as such an issue was because of technical quibbles concerning the definition of a cause of action. Id. 154 .

73 This has not, however, been the attitude of the lower federal courts, which have considered this aspect of comity-freedom from inconsistent federal-state adjudications-to be a strong one. See, e.g., Fernandez v. Trias Monge, 586 F.2d 848, 856 (Ist Cir. 1978); Kauffman v. Moss, 420 F.2d 1270, 1273-74 (3d Cir.), cert, denied, 400 U.S. 846 (1970).

74 See, e.g., Procunier v. Navarette, 434 U.S. 555, 561 (1978); O’Connor v. Donaldson, 422 U.S. 563, 576-77 (1975); Wood v. Strickland, 420 U.S. 308, 321-22 (1975); Pierson v. Ray, 386 U.S. 547, 555-57 (1967). See generally Note, "Damages or Nothing"-The Efficacy of the Bivens-Type Remedy, 64 CornelL L. REv. 667 (1979); see also Butz v. Economou, 438 U.S. 478, 496-508 (1978) (qualified immunity for federal officials in actions directly under the Constitution).

Some officials, however, have the advantage of an even broader immunity. A state governor and other executive officials enjoy a sliding-scale good-faith immunity that is widest for those having greatest responsibility and need for discretion. See Scheuer v. Rhodes, 416 U.S. 232, 247-48 (1974). In some circumstances, prosecutors, judges, and legislators have an absolute immunity. See Imbler v. Pachtman, 424 U.S. 409, 430-31 (1976) (absolute immunity for prosecutors in initiating and presenting state's case, but breadth of immunity for administrative and investigattve acts left undecided); Pierson v. Ray, 386 U.S. at 553-55 (judges have absolute immunity for acts within judicial role); Tenney v. Brandhove, 341 U.S. 367, 379 (1951). See also Butz v. Economou, 416 U.S. at 508-17 (in suits directly under Constitution, federal officials enjoy broader than qualified immunity if their state counterparts enjoy broader immunity in $\$ 1983$ actions). 
affirmatively pleaded by the defendant, ${ }^{75}$ in effect imposes an additional requirement on the section 1983 plaintiff's cause of actionthe plaintiff must persuade or the defendant must fail to dissuade ${ }^{76}$ the trier of fact that the defendant acted in bad faith or without any reasonable basis for belief in the constitutionality of his acts.77

Municipalities, however, have no good-faith defense. Owen v. City of Independence, 100 S. Ct. 1398, 1409 (1980). See note 77 infra.

76 Although the qualified immunity is often spoken of as a defense, there has been a split between circuits on the issue whether the burden of pleading the immunity rested with the plaintiff or with the defendant. See Cruz v. Beto, 603 F.2d 1178, 1183 (5th Cir. 1979). Compare, e.g., id. 1183-84 (burden of proof of malice shifted to plaintiff when defendant is executive official claiming he has acted in official capacity) with, e.g., Bivens v. Six Unknown Named Agents of Federal Bureau of Narcotics, 456 F.2d 1339, 1348 (2d Cir. 1972) (burden of pleading the good-faith defense lies with defendant). The Supreme Court has now resolved this circuit split by holding that the defendant has at least the burden of affirmatively pleading his good faith. Gomez v. Toledo, 100 S. Ct. 1920 (1980).

Regardless of the ultimate resolution of the burden-of-persuasion issue, see note 76 infra, it is clear that by putting good faith in issue, the bona fides of the state or local government are questioned more than by litigating merely the question of constitutionality. See text accompanying notes 78-79 infra.

76 Although the Supreme Court did resolve the burden-of-pleading issue, see note 75 supra, Gomez did not reach the issue who bears the burden of persuasion on the question of good faith. See Gomez v. Toledo, 100 S. Ct. 1920, 1924 (1980) (Rehnquist, J., joining the opinion of the Court).

77 The qualified-immunity defense has two parts-a "subjective" test and an "objective" test. Wood v. Strickland, 420 U.S. 308, 321 (1975). By failing either test, the defendant loses his immunity.

Under the "subjective" leg, the defendant is liable if he acted "with "malicious intention" to deprive the plaintiff of a constitutional right or cause him 'other injury." " Procunier v. Navarette, 434 U.S. 555, 566 (1978) (quoting Wood v. Strickland, 420 U.S. at 322). Simple negligence is insufficient to pierce this part of the veil of immunity; rather, it must be shown that the defendant either knowingly or purposefully caused the plaintiff harm. Procunier v. Navarette, 434 U.S. at 566; Bogard v. Cook, 586 F.2d 399, 411-12 (5th Cir. 1978), cert. denied, 100 S. Ct. 173 (1979). The subjective test is a question of fact for the jury. See Pierson v. Ray, 386 U.S. 547, 557 (1967).

Under the "objective" leg, the defendant is liable "if he knew or reasonably should have known that the action he took within his sphere of official responsibility would violate the [plaintiff's] constitutional rights." Wood v. Strickland, 420 U.S. at 322 . What the plaintiff "should have known" is determined with respect to "settled, undisputable law." Id. 32I; accord, Procunier v. Navarette, 434 U.S. at 565.

Although a city has no good-faith immunity, see Owen v. City of Independence, $100 \mathrm{~S}$. Ct. 1398, 1409 (1980), the plaintiff's burden extends beyond showing mere unconstitutional action by an official. Because the doctrine of respondeat superior is not available to a $\$ 1983$ plaintiff, to recover damages from, or obtain equitable relief against, a city, the plaintiff must prove that the official acted pursuant to a city policy. Monell v. Department of Social Servs., 436 U.S. 658, 694 (1978). Mere failure to prevent unconstitutional conduct is insufficient. See Rizzo v. Goode, 423 U.S. 362, 375-77 (1976). Thus, to prevail against a municipality, the plaintiff must show that some official policy is unconstitutional. As a result, the $\S 1983$ plaintiff who sues a municipality, like the $\S 1983$ plaintiff who sues an official, attacks the bona fides of local government more than does a state criminal defendant who merely raises a conventional constitutional defense. See text accompanying notes 78 \& 79 infra. 
To the extent that the section 1983 plaintiff is questioning the bona fides of the state system more than is a criminal defendant, the underlying assumption of comity-that the states may be equally trusted as guardians of federal constitutional rights-is frontally challenged.78 The very nature of a section 1983 damage suit casts this premise of Younger into doubt; only an assumption of good faith, thus begging the section 1983 question, could preserve the theoretical underpinnings of Younger. ${ }^{79}$ The logical reconciliation of the various interests is to leave the plaintiff to his admittedly difficult proof.

\section{Section 1983's Federal-Forum Policy}

The argument for denying preclusive effect to a state-court determination of a federal constitutional issue in the course of criminal proceedings finds its strongest support in the theory that section 1983 implies a preference for a federal over a state forum ${ }^{80}$

The proposed Civil Rights Improvements Act would greatly increase the liability of cities. See S. 1983, supra note 6 (proposed $\$ \$ 1983$ (c)-(d)). See

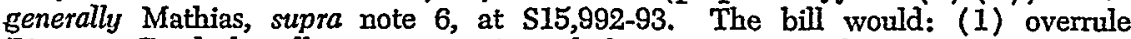
Rizzo v. Goode by allowing injunctive relief against cities whenever an employee violates constitutional rights, see proposed $\$ 1083(\mathrm{c})(2)$; (2) modify Monroe $v$. Pape and Rizzo v. Goode by allowing, in some circumstances, recovery of damages although an official acted contrary to city policy, see proposed $\$ 1983(\mathrm{c})(1)$ (B) -(D); and (3) reaffirm the holding of Owen v. City of Independence that cities have no good-faith immunity, see proposed $\$ 1983$ (d)(I).

78 Of course, a McCurry-type plaintiff is challenging the good faith of a police officer and not that of a judge. It could be argued that police indifference to constitutional rights does not bear on state court respect for these rights. Comity, after all, emphasizes the judicial system, not the executive one. See Stone v. Powell, 428 U.S. 465, 493 n.35 (1976). But local prejudices and passions may well tend to interfere with the objectivity of even a well-meaning and competent state judge. See note 85 infra \& text accompanying notes 82-89 infra. Given a possible overlap of institutional interests between the lower state courts and the local police, see McCormack, supra note 16, at 276, 287, the better approach may be to conduct the relevant inquiry in terms of the "system of criminal justice" as a whole, see Stone v. Powell, 428 U.S. at 494; see id. 490-94, rather than to consider the state judiciary in isolation.

79 See Averitt, supra note 16, at 201-02.

80 When referring to "federal forum," this Comment has in mind direct access to a federal district court, not merely the right of appeal or the right to petition for certiorari from the highest state court directly to the Supreme Court. See 28 U.S.C. \$1257 (1976). Although the contrary has been suggested, see Huffman v. Pursue, Ltd., 420 U.S. 592, 605 (1975), it is difficult to argue that direct review by the Supreme Court fulfills any federal-forum policy that may be found within $\$ 1983$. See England v. Louisiana State Bd. of Medical Examiners, 375 U.S. 411, 416 (1964). Practical considerations dictate against any meaningful federal review on appeal or certiorari. The large volume of cases in the Supreme Court's docket necessarily results in a small chance that any single litigant's petition for certiorari will be granted, see Averitt, supra note 16, at 193, or that any appeal will receive more than a cursory review. Also, direct review does not permit independent federal fact-finding, an often determinative element in constitutional litigation. See England v. Louisiana State Bd. of Medical Examiners, 375 U.S. at 416-17; Averitt, supra note 16, at 193-94. 
for the litigation of federal constitutional claims. ${ }^{81}$ The legislative history of the Civil Rights Act, passed when the federal government was attempting to reassert its authority over the southern states, makes it eminently clear that the sensitivities of the states were the least of the draftsmen's concerns. ${ }^{82}$

Drawing on this historical perspective, the Supreme Court expressly articulated this federal-forum policy in Mitchum $v$. Foster.83 The Court remarked that "[ $t]$ he very purpose of $\S 1983$ was to interpose the federal courts between the States and the people, as guardians of the people's federal rights." 84 Section 1983 was predicated on a positive mistrust of the states' capacity and incentive to play their proper role in the federal constitutional scheme, ${ }^{85}$ and established "the role of the Federal Government as a guarantor of basic federal rights against state power." ${ }^{86}$ Thus, Mitchum states explicitly that section 1983 implies a strong preference for federal court adjudication of federal constitutional claims.

Further, prior to Mitchum, in England v. Louisiana State Board of Medical Examiners, ${ }^{87}$ the Court had already modified the classical model of res judicata to accommodate a section 1983 federal-forum policy by holding that a party forced to abstain from litigating his federal claims in federal court while the state passes

81 Monroe v. Pape, 365 U.S. 167 (1961), overruled in part on other grounds, Monell v. Department of Social Servs., 436 U.S. 658 (1978), held that the presence of a federal forum was in no way dependent on the absence of a state forum. Id. 183.

$82 \mathrm{See}$ id. 172-83.

83407 U.S. 225 (1972). Mitchum held that $\$ 1983$ constituted an express exception to 28 U.S.C. $\$ 2283$ (1976), the Anti-Injunction Act. Id. 243. The Court was very careful, however, to leave intact its holding in Younger v. Harris, 401 U.S. 37 (1971), that although $\$ 1983$ gave the federal courts the power to enjoin state proceedings, considerations of equitable discretion may still preclude them from so doing. 407 U.S. at 243.

84 Id. 242.

85 Id. 240-41. "The United States courts are further above mere local influence than the county courts; their judges can act with more independence, cannot be put under terror, as local judges can; their sympathies are not so nearly identified with those of the vicinage ...." Cong. GLOBE, 42d Cong., 1st Sess. 460 (1871) (remarks of Rep. Coburn), quoted in 407 U.S. at 421 n.31. See also Chevigny, Section 1983 Jurisdiction: A Reply, 83 Hanv. L. Rev. 1352, 1358 (1970).

86407 U.S. at 239. See also Theis, supra note 16, at 866-68 (making the argument that " $[\mathbf{i}] \mathrm{f}$ the Congress passed the legislation in question because it feared that state courts gave only illusory protection to federal rights, it must not have expected prior litigation in those state courts to have a preclusive effect on the plaintiff when he later came to Federal court for protection." Id. 868.). This argument is even stronger in cases such as McCurry's in which the defendant has little choice but to litigate his claim in state court. See text accompanying notes 94-97 infra.

87375 U.S. 411 (1964). 
judgment on his state claims has a right to return to federal court to litigate his federal causes of action. ${ }^{88}$ This right is secured by explicitly reserving the federal question for resolution by a federal court; the right is waived only if the litigant "freely and without reservation" submits his federal claims for decision to the state court. 89

England involved a civil action for injunctive and declaratory relief by a group of chiropractors challenging the validity of a state licensing statute on procedural-due-process grounds. Forced by the Pullman abstention doctrine ${ }^{80}$ to seek relief first in the state system, the plaintiffs returned to federal court after meeting no success at the state level. The reservation mechanism of England permitted avoidance of the normal application of the rules of res judicata that would bar a plaintiff from relitigating both claims that were previously litigated and claims that could have been considered in a prior action, but were not.91 Considering the inflexibility with which the res-judicata doctrine is traditionally applied, England demonstrates some Supreme Court proclivity for the guaranteed availability of a federal forum for the vindication of federal constitutional claims.

There are fundamental objections to any conclusion that a litigant who has properly invoked the jurisdiction of a Federal District Court to consider federal constitutional claims can be compelled, without his consent and through no fault of his own, to accept instead a state court's determination of those claims. Such a result would be at war with the unqualified terms in which Congress

88 Id. 417.

89 Id. 419. Montana v. United States, 440 U.S. 147, 163 (1979), reaffirms the England doctrine. The Second Circuit, in Lombard v. Board of Educ., 502 F.2d 631 (2d Cir. 1974), cert. denied, 420 U.S. 976 (1975), noted in 88 Harv. L. REv. 453 (1974), has extended England to cover a $\$ 1983$ case in which the plaintiff was not forced to abstain and did not specifically reserve the federal question in state court.

90 The Pullman abstention doctrine, named after Railroad Comm'n v. Pullman Co., 312 U.S. 496 (1941), requires a federal court to abstain from hearing a federal constitutional claim in certain instances when a state court could resolve the matter on state-law grounds. See generally Field, Abstention in Constitutional Cases: The Scope of the Pullman Abstention Doctrine, 122 U. PA. L. REv. 1071 (1974).

The proposed Civil Rights Improvement Act would abrogate Pullman abstention in $\$ 1983$ actions, except for abstention while certifying a question to the state supreme court. See S. 1983, supra note 6, at $\$ 2$ (proposed $\$ 1983(\mathrm{e})(\mathrm{i})(\mathrm{c}))$.

91 See J. Moone, supra note 19, at [1 $0.405[3]$. 
.. . has conferred specific categories of jurisdiction upon

the federal courts .....92

At the same time, England's holding barring the relitigation of any constitutional claim freely pressed in the state proceeding ${ }^{93}$ suggests that no federal-forum policy within section 1983 is sufficiently overwhelming to negate the various res-judicata policies entirely.

Despite somewhat distinctive factual patterns, the England result implies that a McCurry-type plaintiff should not be collaterally estopped, regardless of the particular constitutional claim asserted. Such a plaintiff, of course, has actually litigated his claim on the state level. But McCurry, and all other similarly situated criminal defendants, did not "freely and without reservation" 94 press his claim. It is hardly realistic to expect a state criminal defendant to forgo any opportunity to avoid conviction and imprisonment in order to preserve a speculative possibility of recovering damages..$^{95}$

It is true that England-with its primary focus on the deleterious effect of the Pullman-abstention doctrine-could be read narrowly as a comment only on abstention, and not as an affirmative endorsement of a federal-forum policy. ${ }^{96}$ But the spirit of England dictates otherwise. If England is given the not unreasonable reading that it creates a right to a federal forum, then that right has content only to the extent that injured individuals are able to seek relief freely under it. If the position is adopted that a state criminal defendant, under intolerable pressures to litigate any constitutional claim at his state trial, has voluntarily waived his right to a federal forum, the federal-forum right may be deprived of all meaning. ${ }^{97}$

92 England v. Louisiana State Bd. of Medical Examiners, 375 U.S. at 415 (footnote omitted).

93 Id. 419. Accord, Lombard v. Board of Educ., 502 F.2d at 636-37. See also Theis, supra note 16, at 874-75. The England Court noted that "evidence that a party has been compelled by the state courts to litigate his federal claims there will of course preclude a finding that he has voluntarily done so." 375 U.S. at 421 n.12. See note 95 infra.

94 England v. Louisiana Bd. of Medical Examiners, 375 U.S. at 419.

95 One federal court has characterized this option as "a Hobson's choice"no choice at all. Moran v. Mitchell, 354 F. Supp. 86, 88 (E.D. Va. 1973). See also Section 1983 Developments, supra note 3, at 1340; ILr. Note, supra note 16, at 97.

The dilemma becomes even more one-sided when one considers the risk of being caught in a web of state procedural-bypass rules under which his failure to litigate any claim may prevent him from obtaining state or federal habeas-corpus relief. See Wainwright v. Sykes, 433 U.S. 72 (1977).

${ }^{96}$ See Field, supra note 90, at 1078-79.

97 See Mildner v. Gulotta, 405 F. Supp. 182, 206 (E.D.N.Y. 1975), aff'd mem., 425 U.S. 901 (1976). 
The precise contours of this federal-forum policy have not yet been defined. For example, Huffman v. Pursue, Ltd. ${ }^{98}$ implies that the broad reading of England suggested above may be inaccurate. In Huffman, an adult-movie-house operator seeking a section 1983 injunction against the enforcement of a quasi-criminal state statute that would have closed his business ${ }^{99}$ argued that the ever-expanding Younger doctrine, ${ }^{100}$ mandating exhaustion of all state appellate remedies prior to instigation of section 1983 litigation, was inapposite because of the absence of any civil analogue to federal habeas corpus.101 Justice Rehnquist, writing for the Court, rejected this argument on Younger-comity grounds stating:

[Plaintiff's] argument ... apparently depends on the unarticulated major premise that every litigant who asserts a federal claim is entitled to have it decided on the merits by a federal, rather than a state, court. We need not consider the validity of this premise in order to reject the result which appellee seeks. Even assuming, arguendo, that litigants are entitled to a federal forum for the resolution of all federal issues, that entitlement is most appropriately asserted by a state litigant when he seeks to relitigate a federal issue adversely determined in completed state court proceedings. ${ }^{102}$

Subsequent dictum erodes England's federal-forum policy:

We in no way intend to suggest that there is a right of access to a federal forum for the disposition of all federal issues, or that the normal rules of res judicata and judicial estoppel do not operate to bar relitigation in actions under 42 U.S.C. $\S 1983$ of federal issues arising in state court proceedings. ${ }^{103}$

A broad interpretation of this language suggests that the Supreme Court is not inclined to open the federal courts to McCurry-type plaintiffs. The dictum and holding together take with one hand what is given with the other-if a litigant, after exhausting all state remedies, is estopped from effectively asserting a federal claim, whatever right of access to a federal forum exists

98420 U.S. 592 (1975).

99 Id. 595-98.

100 See text accompanying notes 57-61 supra.

101 Huffman v. Pursue, Ltd., 420 U.S. at 605.

102 Id. 606 (emphasis in original).

103 Id. n.18. 
is basically meaningless. ${ }^{104}$ Interpreted in this light, Huffman cuts rather substantially into the spirit of England. ${ }^{105}$

Because Huffman involved a question of equitable restraint, and not the issues of comity and preclusion, the precedential value of this dictum is weak. More on point is Montana v. United States, ${ }^{106}$ in which the plaintiff, attempting to avoid the effects of collateral estoppel, had freely and voluntarily litigated his federal claim in state court. ${ }^{107}$ Although the Supreme Court sustained the application of collateral-estoppel doctrine on these facts, ${ }^{108}$ the Court also reaffirmed the doctrine's flexibility noting that there are "special circumstances [that] warrant an exception to the normal rules of preclusion." 109 The Court's explanation of one of these exceptions renews the vitality of England. Apparently, collateral estoppel would not be applied in a case that "implicate[d] the right of a litigant who has 'properly invoked the jurisdiction of a Federal District Court to consider federal constitutional claims,' and who is then 'compelled, without his consent . . . , to accept a state court's determination of those claims." " 110

In sum, collateral estoppel is a technical, yet flexible, doctrine whose application in any legal scenario depends on the various policies discussed above. The independent policies favoring an estoppel over and above its traditional justifications are weak. Section 1738 provides a weak statutory basis on which to build a system of preclusion jurisprudence. Notions of federal-state comity are significant only when the integrity of a state judgment would be undermined. Reference to comity is equally inappropriate when the federal cause of action challenges the very foundation on which the state judgment is based.

On the other hand, there is a substantial independent policy rationale for relaxing the normal rigors of issue preclusion in McCurry-type suits. Section 1983 evinces substantial concern, possibly rising to the level of a right, with giving a litigant at least

104 See McCormack, supra note 16, at 273.

105 Justice Rehnquist also took a narrow view of the plaintiff's right to a federal forum when the constitutionality of a state statute is challenged and the state court has upheld the provision, relying on the right of direct appeal to the Supreme Court. 420 U.S. at 605. See 28 U.S.C. $\$ 1257(2)$ (1976). In contrast, McCurry's challenge to the constitutionality of police behavior may only reach the federal courts through a petition for certiorari, which is less than satisfactory. See note 80 supra.

100440 U.S. 147 (1979). See notes 69-71 supra \& accompanying text.

107 See text following note 73 supra.

108 See notes 70 \& 71 supra \& accompanying text.

109 Montana v. United States, 440 U.S. at 155.

$110 \mathrm{Id} .163$. 
one chance to litigate any constitutional issue in federal court. A wooden application of collateral estoppel would frustrate this right. Thus, on balance, absent other considerations that may arise, collateral estoppel should not bar the relitigation of issues crucial to a McCurry-type suit for damages, even if they have been previously decided in a state criminal proceeding.

\section{The Avamability of Federal Habeas Corpus}

Final verification of the tentative conclusion just expressed must await consideration of the argument implicit in McCurry $v$. Allen ${ }^{111}$ that the availability of federal habeas-corpus relief is sufficient to fulfill any federal-forum requirement of section 1983.112 The question is whether the availability of habeas for certain issues should operate to bar some $M c C u r r y$-type plaintiffs from relitigating their constitutional claims. ${ }^{313}$ This Comment argues that the distinctions between the habeas-corpus remedy and section 1983 damages compel the conclusion that the availability of habeas corpus is irrelevant to the issue whether a prior determination incident to a state criminal proceeding should estop a section 1983 damage claim.

Prior to analyzing the habeas-availability criterion, a digression is necessary to establish that, despite some intimations to the contrary, section 1983 plaintiffs asserting fourth-amendment claims should not be in a disfavored position as a result of the nature of their constitutional claim. Specifically, Stone v. Powell,114 which mandates unfavorable treatment for fourth-amendment habeas claims, in no way denigrates the constitutional right itself. Stone merely holds that the benefits of vindicating fourth-amendment rights through habeas corpus are outweighed by the costs; the incremental deterrence of illegal police behavior by means of this tardy application of the exclusionary rule is not worth the price of freedom for the guilty. ${ }^{115}$

If we view Stone as a comment on the costs of the "remedy" rather than a statement on the quality of the right, then a section 1983 proceeding should be embraced by a majority of the Court.

111606 F.2d 795 (8th Cir. 1979), cert. granted, 100 S. Ct. 1012 (1980).

112 See note 15 supra \& accompanying text.

$113 \mathrm{McCurry}$, of course, is asserting a fourth-amendment claim for which habeas review is not available. See note 13 supra. Application of this criterion, therefore, would save McCurry from being estopped.

114428 U.S. 465 (1976).

115 Id. 493. It has been suggested that exposure to $\S 1983$ liability would be a greater deterrent to unconstitutional police behavior than the exclusionary rule. See Bivens v. Six Unknown Named Agents of Federal Bureau of Narcotics, 403 U.S. 388, 421-22 (1971) (Burger, C.J., dissenting); McCormack, supra note 16, at 288. 
A section 1983 suit for damages is not nearly as intrusive as habeas relief; because even the successful section 1983 litigant would not gain early release from jail as a direct consequence of his suit, there can be no claim that the federal courts are undoing the efforts of the state criminal-justice system. ${ }^{116}$ Further, to the extent a federal court is concerned with vindicating constitutional rights, a section 1983 proceeding is preferable to habeas corpus. ${ }^{117}$ The habeas remedy-release from custody-bears no rational relationship to the constitutional wrong committed, while a damage award under section 1983 is theoretically tailored to the actual degree of harm.118 Thus, it is not inconsistent to treat fourth-amendment-based habeas petitions unfavorably in relation to other constitutional claims and, concurrently, accord the fourth amendment equal treatment within the context of a section 1983 action.

Returning to the criterion of habeas availability as a determinant of the preclusive effect to be given a previous state judgment in federal court, this Comment reasons that the federalforum policy of section 1983 compels the conclusion that the availability of habeas relief should never permanently prejudice a McCurry-type section 1983 plaintiff. This conclusion can be reached by analyzing both habeas corpus and section 1983 as independent mechanisms designed to remedy constitutional wrongs. But each mechanism's method of correction is different.

Section 1983 damages are designed to be compensatory, and, where possible, should be based on common-law-tort principles. ${ }^{110}$

116 See Stone v. Powell, 428 U.S. at 491 n.31. Cf. text accompanying notes $45-53$ supra (discussion on $\$ 1738$ ).

117 Habeas is primarily regarded as a means of terminating illegal restraint and only secondarily as a remedy for the violation of a constitutional right. See generally Developments in the Law-Federal Habeas Corpus, 83 HaRv. L. Rev. 1038, 1040 (1970).

118 The commonly stated principle of equity that a remedy should be closely tailored to the magnitude of the wrong applies with equal force to constitutional litigation. See, e.g., Carey v. Piphus, 435 U.S. 247, 254-57 (1978).

119 See Carey v. Piphus, 435 U.S. 247 (1978), in which the Court stated:

In some cases, the interests protected by a particular branch of the common law of torts may parallel closely the interests protected by a particular constitutional right. In such cases, it may be appropriate to apply the tort rules of damages directly to the $\$ 1983$ action. . . . In other cases, the interests protected by a particular constitutional right may not also be protected by an analogous branch of the common law of torts. . . In those cases, the task will be the more difficult one of adapting common-law rules of damages to provide fair compensation for injuries caused by the deprivation of a constitutional right.

Id. 258. The Court has maintained a neutral stance on the question of punitive damages. Id. 257 n.II.

See also Note, Damage Awards for Constitutional Torts: A Reconsideration After Carey v. Piphus, 93 Harv. L. Rev. 966 (1980) [hereinafter cited as Harv. Note]. 
For example, the damage award to a state criminal defendant who successfully argued that he suffered from police or prosecutorial misconduct might include a measure of consequential loss such as property or bodily injury and emotional suffering, ${ }^{120}$ and perhaps some compensation for the loss of the constitutional right itself.121 Had the section 1983 plaintiff been unfairly incarcerated, the damage award might include recompense for such harms as lost earnings. ${ }^{122}$ In contrast, the habeas mechanism does not even attempt to compensate for past sufferings; rather, the habeas remedy begins where the section 1983 remedy leaves off. By releasing a defendant from custody, habeas corpus can prevent only future injury. ${ }^{123}$ Thus, the habeas-corpus and section 1983 damage remedies do not overlap. They are mutually exclusive, yet complementary, remedies that together operate to render the injured party whole. Because they should not be interpreted simply as alternative means of access to a federal forum, it is difficult to see why the availability of habeas should preempt the applicability of section 1983.124

\section{Additional Poligy Consmerations}

Having demonstrated that habeas availability should not affect the availability of section 1983 relief, this Comment now turns to

120 Carey v. Piphus, 435 U.S. at 263-64 \& n.22. See Harv. Note, supra note 119; Note, Section 1983: An Analysis of Damage Awards, 58 NEB. L. REv. $580,590-94$ ( 1979 ).

121 The Supreme Court in Carey rejected the idea that substantial damages may be awarded for a procedural-due-process violation without proof of injury distinct from the abridgement of the right itself. Carey, however, does not foreclose the award of such compensation for the violation of "substantive" rights. See HARv. Note, supra note 119, at 978-79. Cf. Halperin v. Kissinger, 606 F.2d 1192,1207 n.100 (D.C. Cir. 1979), cert. granted, 48 U.S.L.W. 3750 (U.S. May 20, 1980) (No. 79-880) (substantial damages available under a Bivens-type cause of action for fourth-amendment violations).

122 This conclusion assumes that deprivation of the right can be said to have "caused" the imprisonment. In cases involving, for example, an involuntary confession, causation would be relatively easy to prove. It is unlikely, however, given the tenor of cases such as Stone v. Powell, 428 U.S. 465 (1976), that a fourthamendment violation would be considered the proximate cause of imprisonment even if but-for causation was demonstrated. See Section 1983 Developments, supra note 3 , at 1352 .

123 Habeas corpus can also provide "belated liberation." Fay v. Noia, 372 U.S. 391, 441 (1963).

124 The reverse side of this argument is that when two modes of relief available in a single forum are duplicative, then the availability of one could rationally be allowed to preclude the availability of the other assuming the existence of other conflicting policies such as comity or repose.

Two Supreme Court decisions have, however, permitted joint access to forums granting obviously supplementary remedies. In Monroe v. Pape, 365 U.S. 167 (1961), overruled in part on other grounds, Monell v. Department of Social Servs., 436 U.S. 658 (1978), the Court dismissed the defendant's argument that an adequate state remedy should preclude relief under $\$ 1983$ : "It is no answer that the 
its central question: how should the federal courts apply the doctrine of collateral estoppel in section 1983 damage suits by state criminal defendants?

This Comment begins with the premise that the broad implications of England-that section 1983 accords a right to a federal forum that is not waived when a criminal defendant attempts to assert a constitutional issue defensively at his state trial ${ }^{125}$-are correct. Because collateral estoppel would effectively frustrate this policy, it should not be applied woodenly to broadly bar relitigation of all constitutional claims. Although federal courts may, in some cases, be compelled to preclude relitigation of certain issues, given the strong federal-forum policy, this result must be justified by resort to other consequential policy considerations.

There are, indeed, at least two reasons why free access to the lower federal courts to litigate section 1983 claims previously decided in a state criminal proceeding should be limited. The first contrasting policy involves constraints imposed by companion doctrines to habeas corpus; the second such policy concerns the ability of society to tolerate inconsistent constitutional adjudications.

\section{A. Companion Doctrines to Habeas Corpus}

Although the court in $M c$ Curry $v$. Allen ${ }^{126}$ was correct in implying that the availability of habeas-corpus relief affects the availability of section 1983 damage relief, that implication's validity

State has a law which if enforced would give relief. The federal remedy is supplementary to the state remedy, and the latter need not be first sought and refused before the federal one is invoked." Id. 183. In Alexander v. Gardner-Denver Co., 415 U.S. 36 (1974), the Court held that access to the "forum" of union-management arbitration for relief from racial discrimination did not foreclose a suit for damages in federal court under title VII. Id. 47 \& n.7. Thus, at first glance, both cases permit access to alternate forums according supplementary remedies.

On closer inspection, however, these holdings rest on the idea of inequality of the respective forums in terms of the relief available. In Monroe, the comparison was between state and federal-not two federal-forums; it was the sense of the Court that the theoretical state remedy was not available in practice. See Monroe v. Pape, 365 U.S. at 174-80. In Alexander also, only one of the forums in question was federal. Further, the Alexander plaintiff had received no relief at the hands of an arbitrator. Had the nonfederal forums been in a position and of a disposition to provide full relief for the federal wrong, both courts might have reached different results. See Alexander v. Gardner-Denver Co., 415 U.S. at 51 n.14.

Even acknowledging this analysis, both Monroe and Alexander can be read to the effect that the existence of one forum providing a remedy distinct from the remedy of another forum should not preempt the availability of the second forum. Because the two cases permit joint access to forums providing duplicative remedies, one would speculate that the courts would also permit joint access to forums offering different forms of relief.

125 See text accompanying notes 87-97 supra.

126606 F.2d 795 (8th Cir. 1979), cert. granted, 100 S. Ct. 1012 (1980). 
rests on a wholly different rationale than the one suggested in the opinion. The availability of habeas is relevant only because of the practical impact of the habeas-exhaustion requirement, and not because of any theoretical arguments revolving around the federalforum policy.

No collateral-estoppel rule for section 1983 actions by prior state criminal defendants should be permitted to undermine habeasexhaustion requirements. ${ }^{127}$ Habeas exhaustion requires state prisoners to pursue all state remedies before seeking federal relief. This embodiment of comity policies ${ }^{128}$ has been scrupulously protected by the Supreme Court. For example, in Preiser v. Rodriguez, ${ }^{129}$ the Court held that granting injunctive relief under section 1983 to force the restoration of a state prisoner's good-time credits would not be an appropriate exercise of federal equity powers. According to the Court, such a remedy would be tantamount to granting habeas, thus effectively circumventing the exhaustion requirement. ${ }^{130}$

The Supreme Court subsequently stated that exhaustion is not required for section 1983 damage actions despite the propriety of delaying injunctive relief. ${ }^{131}$ The Court apparently reasoned that a suit for damages was not as destructive of the original state judgment as injunctive relief. And there is some logic to this position; an injunctive remedy is indistinguishable from habeas corpus whereas monetary damages have an entirely different effect. ${ }^{132}$ But, as a practical matter, a fully litigated damage suit would so effectively preordain the outcome of concurrent state proceedings ${ }^{133}$ that exhaustion would be a dead letter. Despite this practical reality, it is not necessary to bar suit entirely by way of collateral estoppel in order to preserve the exhaustion requirement.

This distinction in exhaustion requirements based on the nature of the remedy was put into sharp focus by two companion

127 See 28 U.S.C. $\$ 2254$ (b) (1976).

128 See Fay v. Noia, 372 U.S. 391, 418 (1963).

128411 U.S. 475 (1973).

$130 \mathrm{Id}$. 488-99. This holding was reaffirmed in Wolff v. McDonnell, 418 U.S. $539,554-55$ (1974), but has been cast into doubt by a footnote in a more recent case involving the Younger doctrine. See Juidice v. Vail, 430 U.S. 327, 339 n.16 (1977).

131 See Wolff v. McDonnell, 418 U.S. at 554-55. See also Preiser v. Rodriguez, 411 U.S. at 494.

132 See notes 129 \& 130 supra \& accompanying text.

133 See Wolff v. McDonnell, 418 U.S. at $554 \mathrm{n} .12$ (noting that normal principles of res judicata would apply). 
cases in the Fifth Gircuit. Both Fulford v. Klein ${ }^{134}$ and Meadows v. Evans ${ }^{135}$ involved $M c$ Curry-type factual situations. Fulford attempted to sue various police and prosecutorial officials for section 1983 damages, alleging that certain exculpatory evidence was withheld at his trial.130 Similarly, Meadows attempted to sue on a claim that his confession was involuntary. ${ }^{137}$ The result was identical in both cases-the federal court could not entertain the section 1983 claims until the plaintiffs had exhausted their respective state remedies. ${ }^{138}$

Given the state of Supreme Court jurisprudence at the time these opinions were drafted, ${ }^{139}$ the Fifth Circuit, in effect, had to rewrite the law to arrive at this conclusion. The court reasoned that the availability of section 1983 relief was not keyed to the form of the remedy, but rather to the nature of the underlying claim; "where the basis of the claim goes to the constitutionality of the state court conviction," ${ }^{140}$ the Fifth Circuit would require exhaustion. ${ }^{141}$ The court grounded its decisions on the comity policy, stating that if such suits were indiscriminately permitted, "any concurrent state action would be an exercise in futility."142

Judge Tjoflat, concurring in part in, and dissenting in part from, the en banc affirmances of Fulford ${ }^{143}$ and Meadows, ${ }^{144}$ would have gone further. He would have dismissed both claims with prejudice on the ground that the plaintiffs were collaterally estopped from relitigating the constitutional issues decided against them in the course of their respective state trials. ${ }^{145}$ Judge Tjoflat's

134529 F.2d 377 (5th Cir. 1976), aff'd en banc, 550 F.2d 342 (5th Cir. 1977) (per curiam).

135529 F.2d 385 (5th Cir. 1976), aff'd en banc, 550 F.2d 345 (5th Cir.) (per curiam), cert. denied, 434 U.S. 969 (1977).

136 Fulford v. Klein, 529 F.2d at 378-79.

137 Meadows v. Evans, 529 F.2d at 386.

138 Id. 386; Fulford v. Klein, 529 F.2d at 382.

139 See text accompanying notes 131 \& 132 supra.

140 Fulford v. Klein, 529 F.2d at 381.

141 See Guerro v. Mulhearn, 498 F.2d 1249, 1253 (1st Cir. 1974). But see Smallwood v. Missouri Bd. of Probation \& Parole, 587 F.2d 369, 371 (8th Cir. 1978) (dictum); United States v. Lightcap, 567 F.2d 1226, 1230 (3d Cir. 1977); Williams v. Ward, 556 F.2d 1143, 1150 (2d Cir.), cert. dismissed, 434 U.S. 944 (1977).

142 Fulford v. Klein, 529 F.2d at 381 . The court went even further, declaring that the suit by Fulford was "a thinly disguised circumvention of state remedies." Id.

143 Fulford v. Klein, 550 F.2d at 344 (Tjoflat, J., concurring in part and dissenting in part).

144 Meadows v. Evans, 550 F.2d at 353 (Tjoflat, J., concurring in part and dissenting in part).

145 Id.; Fulford v. Klein, 550 F.2d at 344 (Tjoflat, J., concurring in part and dissenting in part). 
reliance on significant appellate authority in support of his position ${ }^{146}$ reflects his discomfort with the Supreme Court's apparent discarding of the exhaustion requirement in section 1983 damage suits. ${ }^{147}$

Neither the majority nor Judge Tjoflat explains precisely why permitting the section 1983 damage suit to proceed would circumvent state remedies or render the concurrent state action futile. Neither opinion even attempts to explain away Monroe $v$. Pape's ${ }^{148}$ express statement that federal and state remedies could harmoniously supplement each other. ${ }^{140}$

The absence of any such analysis is even more surprising given the rather obvious effects of a complete federal adjudication on an ongoing state proceeding. First, the federal judgment could have a collateral-estoppel effect on the state proceeding. This preclusive effect is possible in either of two cases: (1) if the section 1983 plaintiff were suing the state jointly, ${ }^{150}$ in which case the state would be a party and therefore bound by the decision; or (2) if the state played a significant role in defending the suit, and was thereby sufficiently connected with the litigation to be bound by the result. 151 In either case, the federal litigation would intrude unacceptably on the state proceeding, thus resulting in many of the evils Younger and exhaustion were designed to cure. ${ }^{152}$ Second, even in the absence of a technical estoppel, given the preeminence of the federal courts in protecting federal constitutional rights, a state court considering the same issue subsequent to the federal determination would, as a practical matter, find it difficult to ignore the federal holding and judge the claim de novo. Although the state court might not be legally bound, ${ }^{153}$ comity flowing from the federal to the state system might compel the same result.

146 Meadows v. Evans, 550 F.2d at 350 n.19 (Tjoflat, J., concurring in part and dissenting in part).

147 See text accompanying notes 131 \& 132 supra.

148365 U.S. 167 (1961).

$149 \mathrm{Id}$. 183. See also note 124 supra.

150 Municipalities can be held liable in $\$ 1983$ actions. See Monell v. Department of Social Servs., 436 U.S. 658 (1978).

151 See, e.g., Montana v. United States, 440 U.S. 147, 154 n.5 (1979).

152 This result is suggested by Samuels v. Mackell, 401 U.S. 66 (1971), a companion case to Younger, which held that declaratory relief is inappropriate in those situations in which Younger precluded equitable relief. See notes 57-6I supra \& accompanying text. One reason justifying the holding was the possible collateral-estoppel effect on the concurrent state proceeding. Samuels v. Mackell, $40 I$ U.S. at 72. See also Duks Comment, supra note 59, at 536-37 \& n.55.

153 See Clark v. Lutcher, 436 F. Supp. 1266, 1271 (M.D. Pa. 1977); Section 1983 Developments, supra note 3, at 1347-48; Duse Comment, supra note 59, at 537 n.35. 
Thus, without some form of exhaustion requirement grafted onto section 1983, a clash of comity policies results and the state is deprived of the initial opportunity to correct their own constitutional errors. This friction is indefensible given the ease with which exhaustion could be added to section 1983 jurisprudence by delaying the federal action until all state remedies are exhausted.154

Of course, there is some cost to the plaintiff associated with delaying the suit for damages. But the plaintiff's interest, when balanced against the state interests in orderly proceedings embodied in exhaustion requirements, is de minimis. Because the section 1983 plaintiff is receiving retrospective compensation for historical harms, he should be relatively indifferent to the timing of his monetary award. 165

Judge Tjoflat's solution-granting collateral-estoppel effect to state determinations of federal constitutional issues-suffers from the simultaneous evils of over- and under-inclusiveness. On the one hand, his uniform collateral-estoppel rule would sweep too narrowly. Given the rather stringent conditions precedent for the application of an estoppel, ${ }^{156}$ there may be cases in which the state adjudication of the constitutional issue was insufficient to warrant preclusion. Yet this technical failure bears no relevance to the issue whether to apply classical exhaustion doctrine. On the other hand, Judge Tjoflat's solution would also be overbroad. Exhaustion requires one only to forbear, not to forgo. Further, Judge Tjoflat's rule would also apply to state defendants found innocent or to those who were found guilty but not imprisoned. Current law imposes no exhaustion requirement on such section 1983 plaintiffs, and there is little reason why any such requirement should be grafted onto existing doctrine.

Concern with reliance on what is basically equitable discretion to alter the availability of a legal remedy should not cause the courts to thoughtlessly adopt an available legal doctrinecollateral estoppel-simply because its application approximates the desired results. Broad statutes such as section 1983 are amenable to well-crafted judge-made qualifications designed to preserve the integrity of other more specific statutes. ${ }^{157}$

154 See part V(A) infra. But see S. 1983, supra note 6, at $\$ 2(e)(2)$, expressly rejecting an exhaustion requirement for $\$ 1983$.

155 An interest adjustment might adequately compensate for the economic costs of delay. But see Section 1983 Developments, supra note 3, at 1354 .

156 See notes 19-23 supra \& accompanying text.

157 See Preiser v. Rodriguez, 411 U.S. 475, 488-90 (1973). 
Thus, the rule of the Fulford and Meadows majorities ${ }^{168}$ appears to be better reasoned than Judge Tjoflat's proposal to indiscriminately apply collateral-estoppel doctrine.

A second companion doctrine to habeas corpus potentially restricting the availability of section 1983 damage relief is the procedural-bypass rule of Wainwright $v$. Sykes. ${ }^{169}$ The scenario implicated involves a state criminal defendant who fails, for whatever reason, to press his constitutional claim during his state trial, as required by state procedures. Wainwright would totally foreclose federal habeas relief to such a defendant, absent a showing of cause and prejudice. ${ }^{160}$ Allowing a section 1983 plaintiff to recover damages on these facts, though he would be blocked by Wainwright from seeking habeas relief, permits him to recover in damages what he could not recover by habeas-consequential damages for his "illegal" imprisonment. ${ }^{161}$

Although the procedural-bypass policy was not a motivating force, at least one court has concluded that a state criminal defendant should be collaterally estopped from relitigating any constitutional issues in federal court that could have been, but were not, raised at his underlying criminal trial, "if there is reason to believe that the failure to litigate the matter in fact was a recognition of the validity of the opposing claim." 162 To the extent that procedural bypass might be a valid concern, this holding is too harsh. The bar must be grounded in the theory that criminal defendants will withhold defenses at state trials because section 1983 damages-litigated in an allegedly more favorable federal forum-will fully compensate them for their illegal imprisonment. But only an abstract-theoretical economist would argue that money damages could ever adequately compensate a human being for his illegal incarceration. ${ }^{163}$ And even if one accepts the economist's questionable position, the better rule would be to restrict the section 1983 damage award to exclude damages arising from imprison-

158 See text accompanying note 138 supra.

159433 U.S. 72 (1977).

180 Id. 87. Before Wainwright, a defendant who did not take advantage of available state remedies was foreclosed from seeking habeas relief only if the defendant had "deliberately by-passed" state procedures at trial. Fay v. Noia, 372 U.S. 391, 438 (1963).

161 See note 122 supra \& accompanying text. But see note 163 infra \& accompanying text.

162 See Palma v. Powers, 295 F. Supp. 924, 936 (N.D. Ill. 1969) (footnote omitted). This conflicts with traditional requirements for the application of collateral estoppel. See note 21 supra \& accompanying text.

163 See Fay v. Noia, 372 U.S. 391, 399-402 (1963). 
ment, ${ }^{164}$ thus offering no economic incentive to a criminal defendant to forsake his constitutional remedies at the state level.

\section{B. Limited Tolerance of Inconsistent Constitutional Adjudications}

Although the grafting of an exhaustion requirement onto section 1983 merely delays suit, there are some situations in which the possibility of inconsistent adjudications in the state and federal systems may necessitate complete federal abstinence. In these circumstances, collateral estoppel should be applied.

A victorious section 1983 plaintiff receives, at most, compensatory, and perhaps punitive, damages. ${ }^{165}$ Assuming he lost the same claim in state court, his continued imprisonment produces an uncomfortable result-a man remains incarcerated because of an error by a state judge and, despite a federal finding of unconstitutionality, does not necessarily have any method to escape what is arguably an illegal imprisonment. Of course, some toleration of inconsistent adjudications is necessary whenever collateral estoppel is eschewed, ${ }^{166}$ but the involvement of constitutional liberties and freedom from physical restraint transcends even the normally potent policy considerations of res-judicata doctrine mitigating in favor of consistency. ${ }^{167}$

All constitutional rights, however, are not identical in this respect. For example, continued incarceration even in the light of a proven fourth-amendment violation can, if one accepts the holding of Stone $v$. Powell, ${ }^{168}$ no longer be considered unjust. Current fourth-amendment jurisprudence makes no link between the validity of the fourth-amendment claim and the defendant's guilt or innocence. ${ }^{169}$ Thus, there is no fear that, by continuing to detain the successful fourth-amendment section 1983 damage litigant, society is unfairly incarcerating an innocent man..$^{170}$

164 Cf. Alexander v. Gardner-Denver Co., 415 U.S. 36, 51 n.14 (1974) (better to allow court to adjust remedy to prevent duplication of remedies than to eliminate remedy altogether).

165 See notes 119-22 supra \& accompanying text.

168 The Supreme Court has implied that the demands of federalism may in fact raise society's tolerance for inconsistent adjudications. See Doran v. Salem Inn, Inc., 422 U.S. 922, 928 (1975).

167 See generally note 25 supra.

168428 U.S. 465 (1976).

I69 Id. 490,492 n.31.

170 Further, the exclusionary rule is a judge-made remedy that is incidental to the right being protected. But see Note, Formalism, Legal Realism, and Constitutionally Protected Privacy Under the Fourth and Fifth Amendments, 90 Harv. L. REv. 945, 985-91 (1977). The failure to apply the exclusionary rule does not tarnish the constitutional right. In fact, Stone suggests that application of the rule 
An analogous result could not be tolerated, however, when constitutional rights implicating the fairness of the trial itself are at stake. For example, a criminal defendant alleging that his confession was coerced in violation of his fifth-amendment rights could not be permitted to relitigate that issue in federal court because, to the extent that the involuntariness of that confession casts the state-court verdict into doubt, his possible innocence would make his continued incarceration intolerable.

Society has provided a mechanism to create consistency in most such cases-habeas corpus. But the proper procedure is to first force the prisoner to seek habeas relief, if available. If the prisoner prevails in the habeas proceeding, he may then proceed to sue under section 1983 for monetary damages. Whatever collateralestoppel effect the original state determination had for the purposes of section 1983 would have been removed by the federal redetermination of the constitutional issue in the habeas proceeding. ${ }^{171}$

Despite the availability of habeas corpus to achieve consistency, some types of cases may still produce inconsistent results if collateral-estoppel doctrine is not applied to section 1983 suits. First, habeas relief may not be available because of a procedural default. ${ }^{172}$ Second, there may be a small class of constitutional claims that could produce a damage award in an unbridled section 1983 suit yet be insufficient to permit habeas relief. This facially anomalous result is theoretically possible because, in a habeas proceeding, the statutory power of the federal court to readjudicate historical facts is severely restricted. ${ }^{173}$ Given the importance of such facts in constitutional cases, ${ }^{174}$ there may be cases in which a section 1983 fact finder would find liability while a federal judge hearing a habeas petition would not.

The arguments advanced in this Comment are potentially disturbing. The implication of this line of analysis is that courts must graft a collateral-estoppel doctrine of some form onto section 1983 not to do justice, but rather because society cannot tolerate the appearance that the criminal-justice system has failed to pro-

in the context of a fourth-amendment violation might be considered a "windfall" to the criminal defendant with little deterrent effect on police conduct. Stone v. Powell, 428 U.S. at 490 . Thus, a $\$ 1983$ action has the twin advantages of denying a "windfall" to the defendant and allowing a court to fashion a remedy consistent with the constitutional violation. See text accompanying note 118 supra.

171 See Section 1983 Developments, supra note 3 at 1330-54.

172 See Wainwright v. Sykes, 433 U.S. 72 (1977).

173 See 28 U.S.C. $\$ 2254$ (d) (1976).

174 See note 80 supra. 
duce an equitable result for one particular defendant. But candor is rather essential in this area. One necessary result of the various restrictions on habeas relief-imposed to promote harmonious federal-state relations-is the occasional unjust detention of some state criminal defendants. Collateral estoppel simply allows society to rest a little easier with this result; it does nothing to change or exacerbate it.

\section{A Proposed Accommodation of Conflicting Policies A. Some Guiding Principles}

The various policies and analytic approaches discussed throughout this Comment suggest the form and limits of the doctrine of collateral estoppel as applied to section 1983 damage suits.

- If the section 1983 plaintiff litigated and lost his constitutional claim in the course of his state trial, but was found not guilty, there should be no bar to the immediate relitigation of the constitutional issue in federal court. Because an inconsistent federal adjudication will not reflect on the propriety of the verdict, the federalism concerns raised by the new determination are more than offset by the vindication of the plaintiff's constitutional rights.

- On the other hand, if the section 1983 plaintiff litigated his constitutional claim before the state court, lost that claim, and was found guilty, then the federal court must, at the very least, abstain from entertaining the section 1983 suit until all state forums for adjudicating the previously litigated constitutional claim have been exhausted. Regardless of the availability of federal habeas-corpus relief, relitigation of the constitutional claim in a federal court before all state remedies are exhausted would impermissibly intrude on the course of the state litigation because of the tendency to preordain the result.

After the section 1983 plaintiff has exhausted all state remedies, the federal court may consider hearing the section 1983 dispute. But a new inquiry is first required. Thus, the court must ask whether, assuming the section 1983 litigant prevails, an inconsistent adjudication can be tolerated. If so, the action may go forward; if not, the plaintiff is at least temporarily barred from bringing the suit.

Note that the relevant inquiry at this stage is not the availability of habeas relief. Of course, if habeas is available, the section 1983 plaintiff may first pursue that relief. If he prevails, then the collateral-estoppel effect of the state adjudication is removed. 
If he is unsuccessful, then he is collaterally estopped from pursuing section 1983 relief by both a federal and a state determination.

- Somewhat different rules apply if the state criminal defendant did not litigate his federal-constitutional claims in state court. If he was subsequently found guilty, then the procedural-bypass rule of Wainwright $v$. Sykes ${ }^{175}$ suggests a limitation on his possible recovery, though that rule should not bar his suit entirely. Of course, if a not-guilty verdict was returned, there is no bar to suit under any theory.

\section{B. The Principles Applied}

This Comment's final task is to apply these principles to several factual scenarios, in order to determine the outcome of this proposed test in a number of typical situations.

The first scenario examined is that of McCurry $v$. Allen. ${ }^{176}$ The $M c C$ urry fact pattern-involving a section 1983 suit alleging fourth-amendment violations-presents an easy case. Because the constitutionality of the search does not go to the question of McCurry's guilt or innocence, the possibility of inconsistent adjudications is not troublesome and relitigation of the constitutional issue decided against McCurry in the state suppression hearing should ordinarily be permitted. At the time of McCurry's section 1983 suit, however, his appeal was pending in the state supreme court. Thus, the federal court must abstain from hearing McCurry's constitutional claim until his state remedies have been exhausted.177

Another scenario might involve an allegation of perjured police testimony at trial, which would constitute a violation of the defendant's fourteenth-amendment right to a fair trial.178 A purely technical application of collateral-estoppel doctrine would require the court to go behind the jury's guilty verdict to determine whether the police witness's credibility had been called into question. If not, then the "actually litigated" condition precedent to the application of collateral estoppel would not be met. ${ }^{179}$ The court would also have to determine whether the jury must have believed the witness in question in order to have reached the ver-

175433 U.S. 72 (1977). See notes 159-61 supra \& accompanying text. 176606 F.2d 795 (8th Cir. 1979), cert. granted, 100 S. Ct. 1012 (1980). 177 See id. 799.

178 See, e.g., Mastracchio v. Ricci, 498 F.2d 1257 (1st Cir. 1974), cert. denied, 420 U.S. 909 (1975).

179 See note 21 supra \& accompanying text. 
dict it did. Cases may arise in which the court concludes that a reasonable jury could have reached the verdict it did even if it disbelieved the perjured testimony. ${ }^{180}$ If that is indeed the case, then the necessariness requirement of collateral estoppel would not be satisfied, and no collateral-estoppel effect should be accorded to the verdict. ${ }^{181}$

This Comment's proposed tolerance-for-inconsistent-adjudication standard, however, would necessitate the application of collateral estoppel in all but the most extreme cases. Even if a reasonable jury could have reached the same verdict were the police testimony not perjured, still, it might not have. Enough doubt would therefore be cast on the verdict to prevent relitigation under the inconsistent-adjudication standard. The section 1983 suit should be permitted only if the court is convinced that the perjury was harmless error. ${ }^{182}$

It is true that, in the two factual scenarios just presented, the McCurry test of looking at the availability of habeas would produce the same results. ${ }^{183}$ Under $M c C$ urry, the unavailability of habeas relief to the prisoner claiming a fourth-amendment violation militates in favor of permitting the section 1983 action to go forward. And because habeas would be available to the prisoner alleging the use of perjured testimony, the section 1983 damage action should be estopped. This symmetry should not be surprising because tolerance for inconsistent adjudications-the Iynchpin of this Comment's analytic approach-also helps shape judicial attitudes towards habeas availability. ${ }^{184}$ But the temptation to rely on the less cumbersome, per se test of habeas availability, on the assumption that the results will mirror those of the inconsistent-adjudication standard, must be resisted.

Instances in which the outcome of the two tests will differ are easily imaginable. Cases may arise, for example, in which a state prisoner would have a colorable habeas claim except for some procedural or tactical error in state court. ${ }^{185}$ In such a case, realizing that it has no jurisdiction to hear the potential section 1983 plaintiff's habeas claim, the federal court may be tempted to give the plaintiff "half a loaf" in the form of monetary damages under

180 See note 34 supra \& accompanying text.

181 See note 23 supra \& accompanying text.

182 See Chapman v. United States, 386 U.S. 18 (1967).

183 See McCurry v. Allen, 606 F.2d at 799.

184 See Stone v. Powell, 428 U.S. 465, 491 n.30 (1976).

185 See Wainwright v. Sykes, 433 U.S. 72 (1977); notes 159-61 supra \& accompanying text. 
section 1983. Such a result would be consistent with the habeasavailability test, but, with certain constitutional claims and the proper factual circumstances, would simultaneously clash with the inconsistent-adjudication standard. ${ }^{186}$

Of course, McCurry's habeas-availability test could be modified to repair this inconsistency by adding an analysis whether the federal court could have entertained a habeas petition but for the defendant's procedural default. Even with this modification, however, there are scenarios in which the two tests would yield substantively different results. One example would involve a fifth-amendment claim arising from a subpoena of an individual's personal papers. The state criminal defendant could have been rebuffed in his attempt to quash the subpoena in state court, refused an injunction in federal court on Younger grounds, ${ }^{187}$ submitted to the subpoena on pain of contempt, and been convicted and imprisoned.188

Although the circumstances in which a subpoena of personal papers constitutes a fifth-amendment violation are narrow, ${ }_{189}$ such cases do arise. ${ }^{190}$ Despite the rather substantial possibilities of significant reputational injury from this constitutional violation, ${ }^{101}$ the habeas-availability test, even as modified above, results in the application of an estoppel to the section 1983 damage action. Under the proposed test, however, the result would be different. As is

$186 \mathrm{~A}$ similar situation would arise if the defendant had been found guilty in the state criminal trial but was only fined. Habeas is clearly foreclosed to him. See generally 28 U.S.C. 2254 (1976). Under the habeas-availability test, therefore, a $\$ 1983$ suit would be permitted. But there might be a societal problem in permitting the inconsistent adjudication, so under this Comment's proposed test, the $\$ 1983$ suit would be estopped.

187 See notes 57-68 supra \& accompanying text.

188 Cf. Sreter v. Hynes, 419 F. Supp. 546 (E.D.N.Y. 1976) (plaintiff barred by collateral estoppel from relitigating constitutionality of subpoena duces tecum in a $\$ 1983$ injunctive action seeking to quash the subpoena).

189 The situations in which such a subpoena of private papers would constitute self-incrimination is not clear. The papers in question would have to be clearly personal, see Bellis v. United States, 417 U.S. 85, 91 (1974); business papers and tax records, two frequently litigated examples, are not generally protected. See Andresen v. Maryland, 427 U.S. 463 (1976); Fisher v. United States, 425 U.S. 391 (1976).

100 See United States v. Plesons, 560 F.2d 890 (8th Cir.), cert. denied, 434 U.S. 966 (1977) (patient medical records); United States v. Beattie, 541 F.2d 329 (2d Cir. 1976) (letters to personal accountant); In re Bernstein, 425 F. Supp. 37 (S.D. Fla. 1977) (tape recordings of personal telephone conversations).

191 See, e.g., State v. Tsavaris, 382 So. 2d 56 (Fla. Dist. Ct. App. 1980) (evidence to the effect that the defendant Tsavaris and one Miss Burton had been engaged in a stormy love affair; that Miss Burton had become pregnant; and that Dr. Tsavaris had compelled her to undergo an abortion despite her unwillingness. to do so). 
true in $M c$ Curry, the constitutionality of the subpoena does not go to the question of the defendant's guilt or innocence. Thus, an inconsistent adjudication could be tolerated. Under this Comment's proposed test, therefore, the section 1983 suit should be permitted to proceed.

\section{CONGLUSION}

In retrospect, it is apparent that the question presented in $M c C u r r y$ transcends the technical aspects of collateral estoppel. The case is actually one in a line of federal cases seeking to determine the proper place for section 1983 in the landscape of constitutional adjudication. This Comment has suggested a possible test for determining when a section 1983 suit for damages raising issues previously litigated in a state criminal proceeding could be heard by a federal court. Although the results under the proposed method of analysis may often be identical with the results achieved under the McCurry habeas-availability test, there are cases in which the result would be entirely different. In any event, it is submitted that this Comment's proposed test rests on stronger theoretical underpinnings. 